REVISTA DE DERECHO UNED, NÚM. 17, 2015

\title{
LA RESPONSABILIDAD DE LOS INVERSORES FINANCIEROS EN ROMA OBLIGADOS ENTRE SÍ POR UN CONTRATO DE SOCIEDAD
}

\section{THE RESPONSIBILITY OF FINANCIAL INVESTORS IN ROME, BOUNDED BY A PARTNERSHIP AGREEMENT AS LIABLE}

PARTIES

María Teresa García LudeÑa

Notaria y Doctoranda en Derecho Romano

Resumen: El actual nivel de los estudios históricos no nos permite mantener conclusiones definitivas en los referente a los orígenes y desarrollo de las instituciones jurídicas, o en la repercusión de ciertos fenómenos, tales como la expansión de las actividades financieras sobre los diversos tipos de sociedades, dando lugar a la aparición de las societates argentariorum. En cualquier caso, una aproximación en profundidad al tema que estamos abordando, entraña un esfuerzo investigativo de los antecedentes históricos, en conformidad con los criterios hermenéuticos recogidos en el artículo 3 del Código Civil. En consonancia con el enorme interés que suscita el panorama actual socio jurídico en lo que concierne a la dicotomía de las relaciones internas y externas de las sociedades consagradas al desenvolvimiento de fines financieros, no he podido resistir la tentación de dirigir la mirada hacia el Derecho Romano en este punto. Hemos tomado la determinación de concentrarnos en el ámbito financiero romano, con el firme propósito de analizar los aspectos más relevantes comprendidos en el funcionamiento de las societates argentariorum.

Palabras clave: Responsabilidad solidaria, cuenta bancaria, contrato de sociedad, socios, obligación solidaria, obligación mancomunada, dolo, culpa, deudor en mora, demanda, demandante, pretor 
Abstract: The current historial studies level does not allow us to mantain definitive conclusions as far as original law constructions are concerned, or even, regarding the impact provoked by certain phenomena, such as, financial activities enlargement over the differents types of societies, giving rise to societas argentriorum emergence. Nevertheless, a Deep approach to the issue we are dealing with, impies an effort at conducting historical experiences research, according to the hermenuethical criteria established in article 3 of our Civil Code. Regardless the huge interest offered by the present legal panorama around the dichotomy of the internal and external relationships of companies, devoted themselves to finantial aims development, I cannot resist the temptation to look towards Roman Law. We have decided to draw reader's attention to Roman financial arena, in order to analyse the most relevant aspects included in societas argentariorum performance.

Keywords: Joint and several liability, bank account, parnership contrat, membership, joint and several obligation, current obligation, fraud, fault,/ofence, delinquent debtor, lawsuit, plaintiff, praetor.

Recepción original: 1/07/2015

Aceptación original: 25/09/2015

Sumario: 1. Configuración subjetiva de sus redes de comunicación: Vestigios de su origen familiar. de la familia a la negotiatio. 2. Un paso más allá: sucesión en la actividad financiera: su impacto sobre la continuidad y seguridad de la responsabilidad societaria. 3. Relaciones internas de los sujetos financieros unidos en societas argentariorum. 4. Configuración de las relaciones externas de las societates argentariorum. 5. Relaciones frente a terceros regidas por el principio de solidaridad.

\section{CONFIGURACIÓN SUBJETIVA DE SUS REDES DE COMUNICACIÓN: VESTIGIOS DE SU ORIGEN FAMILIAR. DE LA FAMILIA A LA NEGOTIATIO}

A finales de la República, e incluso comienzos del Imperio, la mayoría de los negocios financieros, con frecuencia separados de la actividad puramente comercial, no comportaban gran número de socios ${ }^{1}$, aun cuando tuvieran por objeto considerables cantidades de dinero.

\footnotetext{
${ }^{1}$ Situación que se encuentra en contraste con las societas publicanorum, compuestas por un considerable número de miembros.
} 
Respecto negocios de esta índole, debemos tener en cuenta como premisa la distinción siguiente: En el caso en el que los socios son financiera y socialmente desiguales, de suerte que uno de ellos sea comanditario, mientras que los otros, aportando trabajo e industria, aseguran la gestión de la empresa de tal modo constituida. En los ejemplos disponibles, se constata la postura más frecuente: o que los socios socialmente inferiores son los libertos ${ }^{2}$ (sería más insólito que fueran esclavos); o bien que fueran los ingenuos ${ }^{3}$ que no llevaran el mismo apellido o elemento patronímico alguno coincidente con el socio principal. En tal supuesto, sería extraño que llevaran el mismo apellido o que fueran parientes. Es evidente que tal circunstancia repercute directa o indirectamente en la determinación y efectividad de las responsabilidades generadas en el seno de las mismas.

Pero, por otra parte, tomemos en cuenta tres o cuatro ejemplos de sociedades financieras aristocráticas. Hagamos alusión al supuesto de Crassus, a quien Cicerón se dirige en la Sexta Paradoja de los Estoi$\cos ^{4}$. Revisando todas las actividades a las que se consagraba para enriquecerse, Cicerón le reprocha el que se haya asociado cum servis, cum libertis, cum clientibus y les envíe para hacer pillaje en las provincias y arruinarlas por medio de usura (dimissiones libertorum ad deferendas diripiendasque provincias $)^{5}$. En la medida en que llevaba a

${ }^{2}$ GAYO dice: Ingenui sunt, qui liberi nati sunt; libertini, qui ex iusta servitute manumissi sunt.

${ }^{3}$ Ingenuo es la persona que nunca ha estado sometida a esclavitud. La calidad de ingenuo se adquiere por el nacimiento y en el patrimonio el hijo sigue la condición jurídica del padre, fuera del matrimonio, la de la madre.

En referencia a los mismos, afirma Horacio: Liber et ingenuus, praesertim census equestrem.

${ }^{4}$ La VI paradoja ( Que sólo el sabio es rico») está dirigida contra M. Licinio Craso, triunviro y el hombre más rico de su tiempo de lo que se gloriaba. Como en la anterior paradoja mueve su reflexión Marco Tulio en un doble plano: el de «la riqueza de ánimo»versus «riqueza de propiedades». Conviene que te juzgue rico tu ánimo, no el decir de los hombres, ni tus posesiones ¿Estás saciado y aun contento de dinero?, concedo, eres rico; pero si por la avidez de dinero ningún negocio reputas vergonzoso cuando en ese orden puede, ciertamente, haber alguno no honesto; si todos los días defraudas, engañas, pides, pactas, quitas, robas; si despojas a tus socios; hurtas al Erario; si esperas los testamentos de los amigos, o no los aguardas, ciertamente, pero los supones, ¿son estas señales de abundante o de necesitado? El ánimo, no el arca del hombre, suele ser llamado rico; aunque ella esté llena, mientras te veas vacío, no te reputaré rico»

${ }^{5}$ Cic., Par., 6, 46. I. SHATZMAN, 1975, págs. 38 y 377, insiste en el carácter político de los préstamos a Craso y nota que en tales casos, no exigía intereses. Se comprende que Craso no recibía intereses cuando tenía en cuenta el contravalor político que tenía el préstamo que había efectuado; por tanto, los intereses eran puramente políticos. Pero las operaciones a la que Cicerón hacía alusión, y que Craso llevaba a cabo por intermediación de sus dependientes, en calidad de comanditario, tenía como objetivo la obtención de un lucro; cuando se trataba de préstamos, efectivamente llevaban aparejados intereses, del mismo modo que el préstamo de Brutus a los Salamitas de Chipre. 
cabo importantes negocios financieros llevado por su ambición —pudiéndose calificar como «quaestuosus»-, no parecía que Craso mantuviera ninguna relación estrecha de índole financiera con sus parientes, a menos que algunos de ellos formase parte de su clientela. Incluso siendo efectivamente así, resulta interesante comprobar cómo Cicerón los toma en consideración por su condición de clientes y no de parientes.

Otro ejemplo al que podríamos aludir sería el de C. Curtius Mithres, un liberto de C. Rabirius Postumus; dedicado a negocios financieros, que Cicerón recomienda a P. Servilius Isauricus, procónsul de Asia en 46-446.

En época de Cicerón, no era infrecuente que Senadores, caballeros y otros notables italianos prestaran dinero fuera del territorio de Italia, y lo hacían con la colaboración e intermediación de hombres de negocios establecidos en provincias. Entre ellos solía existir un contrato de sociedad o de otra índole similar; pero cualquiera que fuera el nomen de la relación jurídica constituida y las modalidades técnicas de su establecimiento, desde el punto de vista causal, se atribuía al otorgante del préstamo y al intermediario la facultad de obtener un beneficio en la operación.

Caius Verres confía una cantidad de dinero a un tal Publius Tadius, establecido en Atenas; en este caso, probablemente existe una relación de parentesco por parte materna, pues la madre de Verres se llamaba Tadia ${ }^{7}$. Sin embargo, del resto de la documentación disponible no resulta, salvo error, relación alguna de parentesco.

En Italia, incluso, existían intermediarios de crédito que actuaban por cuenta de Senadores y patricios que prestaban dinero a interés; entre ellos existía -aunque no necesariamente siempre- una marcada diferencia de clase social. Y si el intermediario proporcionaba beneficios al Senador, éste, por su parte, ayudaba al financiero por medio de su influencia y sus recomendaciones: He ahí una curiosa definición descriptiva de una sociedad tácita de intermediación financiera bastante asentada, con toda certeza, en la praxis romana.

Cicerón y Pompeyo prestan dinero por intermediación de Cluvius de Pouzzoles, Atticus por medio de Caius Vestorius, Quintus Cicerón por medio de Lucius Egnatius Rufus y Caius Rabirius Postumus colo-

${ }^{6}$ Cic. ad Fam., 13, 69.

${ }^{7}$ Cic. Verr., 1, 100. Un ejemplo de sociedad de reducidas dimensiones con vocación agrícola y comercial, sería aquélla que aparece recogida en la obra Pro Quinctio; Sex. Naevius se casa con una prima hermana de su socio C. Quinctius; por lo tanto, se convierte en su «adfinis». (Véase en particular, 4, 16). 
ca dinero de diversos amigos suyos. La referencia a todos estos nombres, sobre todo la alusión a Cicerón, resulta lo suficientemente clara como para poder descartar toda relación de parentesco o de estrecha alianza entre estos sujetos ${ }^{8}$, posiblemente componentes de una relación contractual surgida por razón de una sociedad de intermediación financiera.

Veamos un segundo enfoque casuístico: Consideremos el supuesto en el que todos los socios o accionistas son, de manera general, iguales, socialmente hablando. Las relaciones de parentesco paterno, ciertas o probables, son más numerosas que en las hipótesis que veíamos en el enfoque anterior. Veamos el ejemplo de dos caballeros Cius y Marcus Fufius, que prestaron dinero a Heraclido de Temnos, y que eran hermanos. Es preciso hacer alusión a aquéllos que llevan el mismo nombre gentilicio, por lo que deben ser próximos agnados (hermanos, o bien padre e hijo, es decir, miembros de la misma familia): Los dos Curtii Postumii, Quintus et Cnaeus ${ }^{9}$; los dos Calpurnii de Pouzzoles, L.j. Capitolinus y C. Calpurnius L.f. [...], quien en época augusta prestaba muy probablemente dinero a los comerciantes, o concluía con ellos contratos de sociedad, verdaderos antecedentes de las sociedades en comandita ${ }^{10}$. Citemos además a los Salustios, a los cuales hizo Cicerón rápidas alusiones, pero que no debían ser forzosamente financieros muy especializados: En el año 58, cuando Cicerón parte para el exilio, Cnaesu Sallustius le acompañó de Roma a Brindes; en el año 47, mientras Cicerón esperaba que César le concediera el perdón, le entrega dinero; este dinero fue reembolsado poco después por Atticus a Publius Sallustius, quien se encontraba en Roma; no se trataba, por tanto, de un préstamo ${ }^{11}$. Respecto a los que no llevan el mismo gentilicio, no obstante, puede existir entre ellos parentesco por línea materna o bien ser afines. De otra parte, teniendo en cuenta que no hay un gran número de sujetos con el mismo gentilicio (y que no necesariamente eran todos parientes entre sí), cabe sacar la conclusión de que dichas relaciones de negocios se entablan con bastante

${ }^{8}$ Quintus Caecilius, tío de Atticus y gran fenerator, era también un intermediario de crédito, y en particular, había colocado dinero de Lucullus, gracias al cual se había convertido en caballero, según Valerio-Máximo $(7,8,5)$. Así se explica que en el año 65 a. JC., Caecilus se convierta en acreedor de P. Varius, a mismo tiempo que Lucullus que Escipión Nasica ( el futuro cónsul en el año 52 a. JC.) y de un tal L. Pontius (ad Att.)

${ }^{9}$ Cic., ad Att., 7, 13, 5; 7, 13. ${ }^{a}$, ; 8, 7, 3; 10, 4, 12; 10, 7, 3. Y Cic., 2 Verr. 1, 102.

${ }^{10}$ CIL X, 1613 y 1797.

${ }^{11}$ Cic., ad Att. 1 1, 3, 3; 1, 11, 1; 11, 11, 17, 1; 11, 20, 2; ad Fam., 14, 4, 6 y 14, 11; ad Quintum fr., 3, 4, 2-3 y 3, 5, 1; De Divn. 1, 28, 59. Los Sallustii, algunas veces, han sido considerados como argentarii, si bien sin suficiente justificación. 
frecuencia entre sujetos que ni son parientes ni afines. En cualquier caso, no es muy frecuente que se desenvuelvan entre agnados ${ }^{12}$.

En cuanto a los banqueros ${ }^{13}$, cambistas y cajeros profesionales o habituales, no alcanzan el rango ni de aristócratas, Senadores, o caballeros; durante los últimos decenios de la República y en el premier siglo del Imperio, en Italia, eran casi todos libertos. Podían constituir pequeñas sociedades, de las cuales tratan fragmentos diversos que figuran en el Digesto ${ }^{14}$; pero, en ninguno de dichos casos, conservamos los nombres de los socios de dichas sociedades. En todo caso, la responsabilidad societaria generada en el seno de las mismas como reacción al incumplimiento de cualquiera de las partes, no presentaría particularidad alguna en cuanto al alcance y a las características propias de la responsabilidad contractual.

No debe pasarse por alto que de la totalidad de las actividades financieras, sólo una parte está en manos de los banqueros, además de que éstos se ocupan también de mutuos sobre géneros y de actividades comerciales sobre objetos no fungibles, de conformidad con los testimonios con los que se cuenta.

Asimismo, la actividad financiera, y por ende la de las sociedades financieras o argentariorum, en Roma no se encuentra ligada por fuerza a un patrimonio inmobiliario ni tampoco a tradiciones ancestrales; a veces resulta del azar de las circunstancias ${ }^{15} \mathrm{y}$ otras veces de la iniciativa particular.

En relación a la clientela bancaria, un solo caso resulta un poco conocido: el de L. Caecilius Jucundus en Pompeya. A lo largo del año 50 d. JC., los Caecilii no desempeñaban ningún papel relevante en la actividad que se refleja en las tablillas descubiertas en 1875. Cada vez que recibe en las subastas un recibo o justificante de pago, Jucundus requiere la presencia de testigos cuyos nombres figuran en el do-

${ }^{12} \mathrm{Al}$ estudiar los patrimonios sucesorios en Pro Cluentio, se observa el debilitamiento del grupo familiar unilineal, la gens. En materia sucesoria, este progresivo atenuamiento tiene lugar en beneficio del conjunto de parientes y afines. En cualquier caso, tratándose del desarrollo de la actividad financiera, siempre hay que tener en cuenta la presencia como sujetos activos de personas unidas por relación de amistad y no de parentesco alguno.

${ }^{13}$ Argentarius, nummularius, coactor argentarius, mensarius, mensularius, trapezi$t a$, se utilizan para designar a los banqueros aparecidos en Roma hacia finales del siglo IV a. JC. Nummularius y coactor argentarius son utilizados con frecuencia desde finales de la República, y en puridad se refieren a las nuevas profesiones bancarias, respectivamente: cambistas y ensayadores de monedas, e intermediarios en subastas.

${ }_{14}^{14}$ 2, 14, 27 pr. (Paul. 3 ed.); 4, 8, 34 (Paul. 13 ed.); 17, 2, 52, 5 (Ulp. 31 ed.); y 2, 14, 9 pr. (Paul. 62 ed.); Véase también Rhet. Her., 2, 13, 19.

${ }^{15}$ Cic. 2 Verr., 1, 90-91. 
cumento. Los nombres de muchos testigos aparecen en las tablillas disponibles, y ninguno de los mismos pertenecía al mismo linaje que Caecilius. Ningún Caecilius es testigo en los recibos y documentación de los archivos municipales. Sucede que en lugar de Jucundus, se lee otro nombre; los que pagan, cuyos nombres sustituyen al de Jucundus se llaman P. Terentius Primus y M. Fabius Agathinus, que no son Caecilii. En otros documentos que recogen titulares de cuentas de depósito en el banco de Jucundus, no se recogen los nombres ni de Caecilius ni de Caecilia.

De todo lo anterior se deduce, que en lo concerniente a la actividad bancaria y financiera, los lazos de parentesco no constituyen su columna vertebral, no se imponen de manera absoluta como estructuras institucionales, alejándose de los perfiles característicos de las incipientes sociedades familiares, y por supuesto del consortium familiae, auténtico modelo o referencia para diseñar fórmulas jurídicas de colaboración para el desarrollo de una actividad económica, como ya hemos tratado en otro momento. Por el contrario, en el siglo I a. JC. Y en el siglo I d. JC., el funcionamiento de las actividades comerciales y económicas en general, contaba con la participación de esclavos y libertos. Así se revela en el texto de Ulpiano, 28 ad ed. ${ }^{16}$ : cuiu mque igitur negotio praepositus sit, institor recte appellabitur... Sed et si in mensa habuit quis servum praepositum, nomine eius tenebitur. (Así, el nombrado para encargarse de un negocio de cualquier tipo, se llamará propiamente factor... Pero si alguno puso a algún esclavo al frente de un banco se obligará en razón de él).

Todo ello obedece al propósito de reforzar una negotiatio, más allá del entorno familiar; es decir, una actividad que presupone una organización con ánimo de lucro.

\section{UN PASO MÁS ALLÁ: SUCESIÓN EN LA ACTIVIDAD FINANCIERA: SU IMPACTO SOBRE LA CONTINUIDAD Y SEGURIDAD DE LA RESPONSABILIDAD SOCIETARIA}

Dos reglas generales parecen explicar las observaciones fragmentarias que se contienen en la documentación disponible.

La primera es que, por una parte, los romanos tienden a heredar, a continuar mortis causa una actividad con más facilidad, cuanto mayor sea su acoplamiento o conformidad a las normas de la vida aristocrática, es decir, más fácilmente, cuanto entrañe mayor patrimonio

${ }^{16}$ D. $14,3,5$, pr. y 3 (Ulp. 29 ed.) 
inmobiliario, más rango, más dignidad. Fruto de su mantenimiento y refuerzo, generalmente por vía hereditaria, estos grupos familiares aristócratas, reciben la denominación de "casas» ${ }^{17}$; concepto que va más allá de los lazos de parentesco «strictu sensu».

Por otra parte, no concurriendo tales perfiles aristocráticos, dado que la actividad financiera exige una cierta riqueza y liquidez (capacidad de asumir responsabilidades), no dependiendo casi de la existencia o ausencia de patrimonio inmobiliario, y además puede someter a desgaste el rango y a la dignidad, resulta que dicha actividad es mucho menos transmisible mortis causa que la agricultura, la explotación de canteras, o de minas, la fabricación de tejas y demás material de construcción, etc.

De acuerdo con la segunda regla, tenemos: Los oficios y profesiones, y las actividades que permiten la ascensión social de quienes las ponen en práctica, en seguida se abandonan si no encajan con el rango del grupo social en que el heredero desea integrarse; o en cambio, si los herederos persisten en tales actividades, éstas se convierten en otra más de sus fuentes de ingresos.

En virtud de esta segunda regla, el hecho de que el bisabuelo de un Senador haya sido comerciante, no prueba en modo alguno la vocación comercial de la aristocracia romana; sino que, por el contrario, constituye la prueba de que el comercio permitía el enriquecimiento y la ascensión social. E incluso demuestra que los descendientes de los comerciantes, si deseaban integrarse en la aristocracia, debían dejar de serlo ellos mismos, o simplemente limitarse a tener intereses en el comercio ${ }^{18}$.

Asimismo, esta segunda regla explica que las profesiones de banquero, cambista o cajero, según la documentación disponible, generalmente sean transmitidas a los libertos y prácticamente nunca a los hijos o herederos. Ni M. Fulcinius, ni el padre de Horacio, ni Titus Flavius Petro (abuelo de Vespasiano) no transmitieron a sus hijos la profesión de argentarius, de coactor o de coactor argentarius; no obstante, ni el hijo de: Fulcinius, ni el de Petro, ni Titus Flavius Sabinus,

${ }^{17}$ Lévi-Strauss la define diciendo que la casa, concepto distinto del de familia, de modo alguno coincide con la línea agnaticia... y más bien consiste en la herencia material y espiritual que comprende la dignidad, los orígenes, el parentesco, los nombres y los símbolos, la posición, el poder y la riqueza. Cfr., LÉVI-STRAUSS, Las estructuras fundamentales del parentesco, Barcelona 1983, págs. 1224-1225.

${ }_{18} \mathrm{~J}$. Andreau trata en esta obra sobre el enriquecimiento, ascensión social y sobre las representaciones a que daban lugar el desempeño de tales actividades financieras por los ascendientes en el contexto social romano. Cfr., ANDREAU, Modernité économique et statut des manieurs d'argent, 1985 MEFRA, 97 págs. 393-410 
se convirtieron en caballeros ${ }^{19}$. Titus Flavius Sabinus desempeñó actividades financieras al igual que su padre; si bien, no fue banquero de profesión; fue publicano en Asia y concedió préstamos a interés en Helvetia. Tal cambio de actividad era signo de ascenso financiero y social $^{20}$. Respecto a Pedro y su nieto Vespasiano, cabe decir que los Flavii conservaban el gusto por el dinero y la actividad financiera, y se dice que, convertido en Emperador Vespasiano, «se consagró abiertamente a la práctica de especulaciones deshonrosas, incluso para un simple particular» ${ }^{21}$; si bien, de generación en generación, a medida que se producía su ascensión social, este tipo de actividad financiera cobra perfiles y formas diferentes. En otros supuestos, por ejemplo, en el caso de Horacio, el gusto financiero en sí no se transmite.

Los dos cajeros, Tjberius Claudius Secundus y Tiberius Claudius Secundus Phillippianus, recogidos en las inscripciones, no transmiten su negocio y explotación a sus hijos.

Diversos fragmentos de Q. Cervidius Scaevola, de Paulo y de Ulpiano figuran en el Digesto ponen de manifiesto que el heredero de un argentarius no practica la profesión del de cuius, y presentan ${ }^{22}$ dicha eventualidad como algo habitual, que no creaba dificultades particulares.

Por otra parte, ciertas inscripciones suponen que el negocio de banquero se haya transmitido por el patrón a su liberto, y el liberto Tiberius Claudius Priscus Secundianus, según se acredita en una inscripción funeraria, sucedió sin duda alguna sucedió, como cobrador y cajero a unos de los dos cobradores homónimos allí nombrados ${ }^{23}$. Surgen los interrogantes siguientes: El viejo banquero, ¿vendía el establecimiento a su sucesor, en el caso que fuera propietario del mismo? ¿Se lo legaba? El sucesor en el negocio, ¿devenía arrendatario del heredero? ¿Se configuraba entre sucesor de negocio y heredero una sociedad tácita? Ante estos planteamientos, las respuestas pueden ser múltiples, las cuales dependerán del contenido del título por el que haya sido designado el sucesor correspondiente. De todos modos, una

${ }^{19}$ Hor., Sat., 1, 6, 86; Cic. pro Caec., 4, 10-11; Suet., Vesp. 1, 2.

${ }^{20}$ Suet., Vesp., 1, 2.

${ }^{21}$ Suet. Vesp., 16, 2: negotiationes quoque vel privato pudendas propalam exercuit...

${ }^{22}$ D. 2, 13, 6 (Ulp. 4 ed.); 2, 13, 9, 1 (Paul. 3 ed.); 14, 3, 20 (Scaev. 5 dig.); 40, 7, 40, 8 (Scaev. 24 dig.). Este último fragmento no parece muy significativo: el banquero pide a sus esclavos, para después de su muerte, que cobren los créditos que aún estaban impagados, a fin de entregar las cuentas a sus herederos. Esta petición se explica posiblemente por la razón de que los herederos no retomaban la profesión del difunto.

${ }^{23}$ CIL. VI, 9187. 
muestra particular de un título de designación nos la ofrece Papiniano al referirse a: Mensae negotium ex causa fideicomiso... (la negociación de un banco, aceptada por causa de fideicomiso.... $)^{24}$. En tal supuesto, el fideicomisario, por la naturaleza de su llamamiento y como continuador de las relaciones jurídicas de su causante, estaría sujeto a las mismas obligaciones del primer causante; debiendo soportar y hacer frente a las responsabilidades pendientes de hacerse efectivas. En todo caso, cualquiera que fuere la forma en la que se estructure la sucesión en la actividad financiera, e incluso en el caso de su desaparición con ocasión del fallecimiento del primer titular y falta de continuidad del negocio post mortem, sobre los sucesores en el negocio, o bien sobre los herederos del causante (no involucrados en el negocio), en su caso, pesa la obligación de exhibición de las cuentas llevadas por el causante, siendo personalmente responsables de ello ${ }^{25}$.

Esta práctica (muy extendida, según parece) de poner en manos mortis causa el negocio del causante en manos de su liberto, y de no transmitir el negocio al hijo, no se limita a los casos de banqueros y cajeros; asimismo se constata en gran número de oficios y profesiones urbanas de artesanía y comercio, que llegaron a ser desempeñadas con harta frecuencia por libertos.

En cuanto a los supuestos de financieros de la aristocracia o próximos a la aristocracia, nos encontramos, mutatis mutandis, ante una situación un poco análoga. Algunas veces, el negocio (como actividad) se transmite al hijo; sin embargo, no existe indicio alguno de su transmisión a las generaciones siguientes. El préstamo de dinero u otras actividades financieras, si se continúan, lo es a una escala reducida, a título de una fuente de ingresos secundaria, y no como una auténtica especialidad.

De todo lo expuesto podemos concluir que los vínculos de parentesco, en materia financiera (y también económica, en su sentido más amplio), no son más estrechos que los lazos de otra índole como de amistad, de relaciones sociales y políticas; incluso si se trata de parientes muy próximos. Sin perjuicio de lo anterior, las relaciones financieras, no siempre instrumentadas a través de contratos de sociedad, se desenvuelven preferentemente en un entorno donde concurren amigos, parientes y afines, y en otro orden de cosas de afines y esclavos, considerados como prolongación del dominus negotii en sí.

${ }^{24}$ D. $31,77,16$ (Pap. 8 resp.)

${ }^{25}$ D. 2, 13, 6, 1 (Ulp. 4 ed.) 
En cualquier caso, en esta época, totalmente desligada del origen familiar de las comunidades, curiosamente el parentesco no domina las relaciones económico-financieras ${ }^{26}$ ni modela las estructuras de las actividades comerciales, ni prima en cualesquiera otras especies distintas de relaciones; sino que la práctica financiera, para hacer frente a las necesidades económicas de una sociedad cada vez más compleja, necesita unir esfuerzos más allá del estricto ámbito familiar. Inevitablemente, la respuesta jurídica exigida por tal orden de cosas, impone una flexibilización que lleve a la búsqueda de fórmulas diversas que permitan la canalización de los esfuerzos colectivos en aras de un fin común ${ }^{27}$, estableciéndose así el caldo de cultivo en el que prolifere la societas argentariorum ${ }^{28}$. En la práctica va más allá de ser una figura contractual; más aún, opera como guía de enlace o punto de encrucijada de otros contratos habituales en la práctica económica y comercial como la compraventa, el arrendamiento, mandato, depósito, etcétera.

\section{RELACIONES INTERNAS ${ }^{29}$ DE LOS SUJETOS FINANCIEROS UNIDOS EN SOCIETAS ARGENTARIORUM}

Como vemos son las necesidades prácticas las que impulsan la celebración de contratos de sociedad ${ }^{30}$ como instrumento por el que se encauce la llevanza de la actividad financiera: así se forja la societas argentariorum ${ }^{31}$ como punto de inflexión para la expansión, en volumen y complejidad de las operaciones bancarias, partiendo de la base de un contrato entre banqueros celebrado con la finalidad de gestionar actividades bancarias ${ }^{32}$, sin que ello implicara necesariamente encomendárselas a un esclavo gerente, propiedad de todos ellos (aunque en realidad, dicha práctica se extiende ya a finales de la

${ }^{26}$ Cfr., ROSTOVZEFF. Historia social y económica del Imperio Romano, Madrid 1962, págs. 21 y ss, con abundante bibliografía sobre la banca y el comercio en el siglo I a. JC. Véase también, KONVALIOV, Historia de Roma, Madrid 1979, págs. 367-370.

${ }^{27}$ Cfr., ARANGIO-RUIZ. La Società, in diritto romano, Napoles 1958, págs. 82 y ss.

${ }^{28}$ Vid., GARCÍA GARRIDO. Societas Argentarii, en Studi in onore di Biscardi. Milano 1982, págs. 373 y ss.

${ }^{29}$ Véase sobre relaciones internas societarias: SERRAO, Sulla rilevanza esterna del rapporto di società in diritto romano, en Studi in onore di E. Volterra V, Milano 1971.

${ }^{30}$ Sobre el concepto y razón del ser de la figura de la societas, véase, Fernández de Buján Fernández, F., Esencia del contrato de sociedad, vista desde la RAE, en RGDR 8 (2007).

${ }^{31}$ Parece tener un origen helenístico, como gran parte de la doctrina señala.

${ }^{32}$ En palabras de GARCÍA GARRIDO. «...era un tipo especial de asociación... para prestar y recibir dinero». Efectivamente ésta era su esencia. Vid., GARCÍA GARRIDO Derecho Privado Romano. Casos, acciones, instituciones; Madrid 2000, § 197, 76. 
República); y sin que, en el hipotético caso de existencia de un esclavo (o incluso liberto) común, se le dotara de un peculio.

En un pasaje de Ulpiano ${ }^{33}$ se describe un supuesto de societas argentariorum enfatizando la relación nominal y estructural -puesto que ambas dependen de un acuerdo (salvo la communio incidens)entre la sociedad y la copropiedad ${ }^{34}$ : Cum duo erant argentarii socii, alter eorum aliquid separatim quaesierat et lucri senserat: quaerebatur, an commune esse lucrum oporteret, et imperator Severus Flavio Felici in haec verba rescripsit:'etiamsi maxime argentariae societas initia est, quod quisque tamen socius non ex argentaria causa quaesiit, id ad communionem non petinere explorati iuris est. (Siendo socios dos banqueros, uno de ellos había adquirido algo por separado y había logrado una ganancia: se preguntaba si debía ser común ese lucro, y el emperador Severo resolvió en un rescripto dirigido a Flavio Félix con estas palabras: Aunque sí hay en principio una sociedad de banca, no obstante, lo que cada socio adquirió por causa ajena al negocio de la banca es de derecho que no pertenece a la comunidad). Dado que en el concreto supuesto, se estima que la adquisición es exógena a la empresa unitaria de banca, el mismo queda al margen de la solidaridad activa y pasiva de los banqueros ${ }^{35}$.

La profesión de banquero tenía carácter privado en Roma ${ }^{36}$.

Como puede advertirse, las relaciones entre los banqueros se rigen por las reglas generales del contrato de sociedad, aun cuando lógicamente podían pactarse ${ }^{37}$ cláusulas especiales que alteraran dicho ré-

${ }^{33}$ D. 17, 2, 52, 5 (Ulp. 31 ed.).

${ }^{34} \mathrm{Sin}$ embargo, en la societas alicuius negotiationis no es imprescindible la copropiedad, aunque el derecho posclásico lo exigió por influjo de las corporaciones. d'Ors apunta que esto favoreció la representación directa por parte de uno de los socios. Cfr., D’ORS, Derecho Privado Romano, Pamplona 1975, § 485.

${ }^{35}$ Dicha solidaridad activa y pasiva aparece atestiguada por Paulo en D. 2,14,25 pr. (Paul. 3 ed.) y 27 pr. (Paul. 3 ed.); y en Ret. ad Herennium 2-13-19.

${ }^{36}$ Sólo en circunstancias excepcionales se organizaron bancos públicos bajo la dirección de funcionarios del Estado; por ejemplo, en época de Tiberio, a raíz de una crisis económica en que la falta de capitales produjo la ralentización del crédito, se hizo necesaria la concesión estatal de créditos a personas que ofrecían garantías de reembolso. Vid., MOMMSEN-MARQUARD, Manuel des antiquités romaines. S. V. argentarii, Tomo 10, París 1888, pág. 79.

${ }^{37}$ Mohino entiende que «El reconocimiento de los pactos adjuntos a los contratos de buena fe alcanza su apogeo a través de los pactos in continenti. Estos pactos se añadían en el momento de la celebración del contrato otorgando la buena fe, de un lado, el reconocimiento a los mismos en virtud del principio de autonomía de la voluntad, de otro, el privilegio que permitía no solicitar la exceptio (no introducir la exceptio expresamente en la fórmula) por lo que el juez debía tener en cuenta todas las convenciones particulares que se habían concluido alrededor del acto principal». 
gimen, principalmente en relación a las aportaciones desiguales de los contratantes, y al reparto de pérdidas y ganancias. En cuanto a las aportaciones, se recuerda que pueden consistir incluso en servicios (socios industriales) ${ }^{38}$, y que el reparto de ganancias está en razón de las aportaciones, o si no constan ser diversas, se distribuyen por partes iguales, del mismo modo que las pérdidas ${ }^{39}$.

Por otra parte, hay que tener en cuenta que la actividad de la societas argentariorum se podía desenvolver en varios lugares distintos, incluso distantes entre sí, lo que parece ser confirmado por la lectura de los pasajes en los que se atestigua que el lugar donde se desempeña la actividad es diferente de aquél en el que se lleva la contabilidad ${ }^{40}$.

Además de estos aspectos comunes a toda sociedad, para el caso de la societas argentariorum, la cláusulas especiales pueden estar referidas a obligaciones específicas de la misma, como es la conservación y exhibición de la contabilidad, dando como resultado dos alternativas: o que la llevara uno solo o todos en común con las consecuencias que se exponen en el pasaje transcrito.

Aun cuando ya hemos apuntado anteriormente a la obligación de los sucesores del banquero de exhibir las cuentas, tal como se recoge en el pasaje de Ulpiano ${ }^{41}$, debemos profundizar más sobre esta obligación concerniente a la elaboración detallada y transparente de la contabilidad social ${ }^{42}$, unida a la publicidad de la actividad de la taberna argentaria como premisa fundamental para hacer valer cualquier género de responsabilidad ${ }^{43}$ nacida del ejercicio propio del fin social, lo cual nos

Vid., MOHINO MANRIQUE, A propósito de D. 19.2.20.2 en relación con D. 19.2.22.pr., en RIDA (1998) pág. 414.

${ }^{38}$ Por ejemplo, aunque no se trata de una sociedad de banqueros, téngase en cuenta el texto de D. 17, 2, 29, 1 (Ulp. 30 Sab.), extensible por analogía al supuesto de societas argentariorum.

${ }^{39}$ GAYO, 3, 150. Incluso puede pactarse la no participación en el riesgo, pero nunca en la ganancia; de esta manera, como ya hemos apuntado, queda prohibida la Sociedad Leonina (D. 17, 2, 29, 2 (Ulp. 30 Sab.))

${ }_{40}$ Por ejemplo, ULPIANO en D. 2,13, 4, 5 (Ulp. 4 ed.) y en D. 2, 13, 6, 9 (Ulp. 4 ed.); también PAPINIANO en D. 5, 1, 45, pr. (Pap. 3 resp.)

${ }^{41}$ D. 2, 13,6,1 (Ulp. 4 ed.)

${ }^{42}$ Como fuentes de información, pueden servir los archivos de Cecilio Jocundo (Etienne afirma que su actividad simboliza el mundo bancario que puede ser estudiado a través de los contenidos de sus tablillas de contabilidad, que de forma completa se recogen en el suplemento al volumen IV del Corpus Inscriptionum Latinarum. Cfr., ETIENNE, La vida cotidiana en Pompeya, Madrid 1996, págs. 187 y ss.), y los de los Sulpicios (como veremos después), actico primero en Puteoli (actual Pozzuoli) y después transferidos a Pompeya.

${ }^{43}$ Sobre el análisis de aquellos textos en los que puede apreciarse claramente la existencia de una controversia doctrinal, entre juristas de la última época republicana y de la primera época clásica, en torno a la diferente protección otorgada a los con- 
lleva al examen de las relaciones de los socios argentariorum con terceros; si bien antes de abordar el desarrollo de las relaciones de los socios argentarii erga omnes, por razón de la relación societaria constituida.

\section{CONFIGURACIÓN DE LAS RELACIONES EXTERNAS DE LAS SOCIETATES ARGENTARIORUM}

Conforme a esta línea de reflexión, conviene recordar (referente al pros que en los fragmentos 3 y 4 de D.14,3,11 se detallan las normas de publicidad que ha de cumplir el contenido del encargo asumido por el praepositus, en la proscriptio o anuncio público por escrito ${ }^{44}$. Esta proscriptio -según reza el fragmento 3- ha de constar en carteles claros donde con facilidad pueda leerse bien, como los que se colocan delante del lugar donde se ejerce el negocio, y no en un sitio escondido, sino en uno visible (Proscribere palam sic accipimus claris litteris, unde de plano recte legi possit, ante tabernam scilicet vel ante eum locum in quo negotiatio exercetur, non in loco remoto, sed in evidenti). El anuncio público también debía de expresarse en una lengua comprensible a los habitantes del lugar, para que nadie pudiera excusarse con su ignorancia de la escritura (litteris utrum Graecis an Latinis? puto secundum loci condicionem, ne quis causari possit ignorantiam litterarum $)^{45}$. Y prosigue D. 14,3,11,3 in fine: si alguno dijese que no sabía leer o que no se fijó en lo que estaba anunciado, cuando muchos lo leyeron y estuvo expuesto en público, no será oído (certe si quis dicat ignorasse se litteras vel non observasse quod propositum erat, cum multi legerent cumque palam esset propositum, non audietur), esto es,

tratantes para exigir su responsabilidad en caso de incumplimiento de pactos in obligatione añadidos al contrato de compraventa, extensibles por analogía, dada su identidad de razón a las relaciones surgidas del contrato de compraventa, extensibles por analogía, dada su identidad de razón, a las relaciones jurídicas surgidas del contrato de sociedad, véase, MOHINO MANRIQUE, Ius controversum y responsabilidad, en RGDR Iustel 23 (2014)

${ }^{44}$ Sobre el carácter genuino de las fuentes relativas al contenido y publicidad de la proscriptio, vid., entre otros, SERRAO. Institor (storia), ED 21, Milano 1971, pág. 829; HAMZA. Aspetti della rappresentanza negoziale in diritto romano, en Index 9 (1980) págs. 206 ss.; KIRSCHENBAUM. Sons, Slaves and Freedmen, Jerusalén 1987, págs. 93 ss.; WACKE. Die adjektizischen Klagen, en Überblick SavZ Rom Abt. 124 (1994) págs. 323 ss.; PETRUCCI. Ulteriori osservazioni sulla protezione dei contraenti, en Studi in onore di Remo Martini, pág. 20; LONGO. Actio exercitoria, actio institoria, actio quasi institoria, en Studi in onore di Gaetano Scherillo II, Milano 1972, págs. 610 ss., con las opiniones de la crítica interpolacionística, al respecto.

${ }^{45}$ Cfr., AUBERT. Business Managers, Leiden, New York, and Köln 1994, pág. 12; WACKE, Gallisch, Punisch, Syrisch oder Griechisch statt Latin? Zur schrittweisen Gleichberechtigung der Geschäftssprachen im römischen Reich, en ZSS 110 (1993) págs. 33 ss. 
no se puede aducir unilateralmente el desconocimiento de la proscriptio cuando es públicamente conocida por todos.

En el fragmento siguiente (D. 14,3,11,4), se prescribe que el anuncio público ha de ser permanente (Proscriptum autem perpetuo esse oportet), pues si se contrató durante el tiempo en que no estaba expuesto o cuando ya se borró, tendrá lugar la acción institoria (ceterum si per id temporis, quo propositum non erat, vel obscurata proscriptione contractum sit, institoria locum habebit). Del examen conjunto de los fragmentos 3 y 4 de D. 14,3,11 se deduce que el cumplimiento de los requisitos de publicidad de la proscriptio en tanto a su redacción en un lenguaje claro y comprensible, como a su fijación en un lugar visible y públicamente accesible, exonera de responsabilidad al empresario que hizo la praepositio en el marco de la actio institoria $^{46}$. Al contrario, la acción se sustancia cada vez que los clientes se encontraran imposibilitados de enterarse del contenido de ésta, inclusive por causas ajenas a la organización de la empresa, tales como: la sustracción de la proscriptio por un tercero o su ilegibilidad debida al paso del tiempo o a los agentes climatológicos (proinde si dominus quidem mercis proscripsisset, alius autem sustulit aut vetustate vel pluvia vel quo simili contingit, ne proscriptum esset vel non pareret, dicendum eum qui praeposuit teneri). Subsiste, igualmente, la acción contra el dominus negotii si el mismo factor de negocios o institor sustrajo dolosamente el anuncio para defraudar a la contraparte, a menos que ésta hubiera sido partícipe del dolo, tal como se expresa claramente en D. 14,3,11,4 in fine (sed si ipse institor decipiendi mei causa detraxit, dolus ipsius praeponenti nocere debet, nisi particeps doli fuerit qui contraxit). Es decir, la responsabilidad objetiva del miembro de la societas argentariorum por los actos realizados en su ámbito empresarial, circunscritos al encargo prescrito al institor, deriva de la imposibilidad que hayan tenido los clientes de conocer el contenido de dicho encargo, siempre por hechos ajenos a los mismos ${ }^{47}$.

En otros fragmentos del mismo texto de Ulpiano que estamos examinando, en concreto en el 2..$^{\circ}$ y el 5. ${ }^{\circ}$, se contienen determinadas cláusulas contractuales a las que se vincula la praepositio y que podemos considerar como verdaderas condiciones generales. Éstas se refieren de conformidad con D. 14,3,11,2- a la prohibición expresa y pública de contratar con un determinado factor o gerente (De quo palam proscrip-

${ }^{46}$ Cfr., WACKE. Die adjektizischen Klagen, cit., págs. 331 ss.

${ }^{47} \mathrm{Cfr}$., PETRUCCI. Sobre los orígenes de la protección dada a los terceros contrayentes, cit., pág. 239. Véase, además, SANFILIPPO, Sulla irrelevanza del rapporto sociale nei confronti dei terzi, en IURA 2 (1951) págs. 159 y ss., y SERRAO, Sulla rilevanza esterna del rapporto di societá in diritto romano, en Studi Volterra 5, 1971, págs. 743 y ss. 
tum fuerit, ne cum eo contrahatur, is praepositi loco non habetur: non enim permittendum erit cum insitore contrahere, sed si quis nolit contrahi, prohibeat), ya que a falta de tal prohibición se entiende que el praeponens se obliga por el mismo nombramiento que hizo (ceterum qui praeposuit tenebitur ipsa praepositione); asimismo, en D. 14,3,11,5 se alude a la inserción de una determinada lex o ciertas cláusulas en los contratos; la necesidad de constituir garantías personales o reales; la limitación a un determinado objeto; el nombramiento de varios institores que actúen conjunta o separadamente y la prohibición ${ }^{48}$ o el permiso de contratar con el institor para cierto género de personas o negociantes (quid enim si certa lege vel interventu cuiusdam personae vel sub pignore voluit cum eo contrahi vel ad certam rem? aequissimum erit id servari, in quo praepositus est. item si plures habuit institores vel cum omnibus simul contrahi voluit vel cum uno solo. sed et si denuntiavit cui, ne cum eo contraheret, non debet institoria teneri: nam et certam personam possumus prohibere contrahere vel certum genus hominum vel negotiatorum, vel certis hominibus permittere).

Se ha de entender que los clientes que no se sujetaran a estas cláusulas unilaterales dispuestas por parte del dominus negotii, no contaban con la actio institoria. Esta regla se deduce del inicio del fragmento $5^{\circ}$, cuando expresamente se prescribe que se han de observar los términos del nombramiento o encargo (Condicio autem praepositionis servanda est), pero también de la parte final del mismo fragmento que sí considera de aplicación la acción, cuando el negotiator variara continuamente las prohibiciones o permisos de contratación con el institor. Y el razonamiento que se aduce es que «no se deben engañar a los contratantes» (sed si alias cum alio contrahi vetuit continua variatione, danda est omnibus adversus eum actio: neque enim decipi debent contrahentes). Efectivamente, una variación de los términos o condiciones generales en la praepositio ${ }^{49}$ supondría una situación de incerti-

${ }^{48} \mathrm{Si}$ se le prohíbe contratar al empleado con terceros, no se le considera institor, sino como un guarda lo que se refleja en D.14,3,11,6 (Ulp. 28 ed.): Sed in totum prohibuit cum eo contrahi, praepositi loco non habetur quum magis hic custodis sit loco, quam institoris. Ergo nec vendere mercem hic poterit, nec modicum quid ex taberna.

${ }^{49}$ A propósito de este tema Di Porto deja claro que no es suficiente la existencia de una praepositio para determinar la configuración de una empresa comercial, «ma è necesario prendere in considerazione sia il GENERE di attività esercitata, sia le MODALITÂ con le quali si svolge». Vid., Di Porto, Impresa collettiva e schiavo manager in Roma antica. II sec. a. C II sec. d. C., Milán 1984, pág. 67. Asimismo Micelli dice «Infatti, la praepositio institoria, ieri come oggi, è un fenómeno dotato dei peculiarità proprie. E' innegabile, infatti, che l'attività di cooperazione svolta in maniera stabile e continuativa, richieda una particolare disciplina rispetto alla cooperazione delegata in maniera episódica». Vid., MICELI. Sulla struttura formulare delle "actiones adiecticiae qualitatis", en NNDI (1957) pág. 207. 
dumbre y, en consecuencia, de desigualdad para la parte más débil de la contratación. Así, el principio «neque enim decipi debent contrahentes»-que no sólo se ha de entender limitado a la hipótesis de incertidumbre provocada por la frecuente variación de prohibiciones para contratar con los institores, sino que se puede suponer de cualquier cláusula general- se convierte en el contrapeso a un régimen de libertad en la fijación unilateral de las condiciones de la contratación, ciertamente favorable al empresario, y es, además, expresión de la buena fe objetiva que se deduce del llamado «riesgo empresarial ${ }^{50}$.

Esta disciplina, articulada en torno a la labor conjunta del pretor y la jurisprudencia, es perfectamente aplicable al ars argentaria. Así el cliente que contrataba con un argentarius en el ámbito de su actividad profesional, tiene a su favor la actio institoria que comporta una responsabilidad ilimitada (in solidum) ${ }^{51}$ de los miembros de la societas argentariorum por incumplimiento de los deberes de información y transparencia referentes al desempeño de sus actividades, así como por una continua variatio de las mismas ${ }^{52}$. Y ello en atención a la bue-

${ }^{50}$ Ya que el empresario responde por el hecho objetivo de contratar en el ejercicio de su actividad empresarial. Vid. SERRAO. Impresa e responsabilità a Roma nell' età commerciale. Forme giuridiche di un'economia-mondo, Pisa 1989 (reed. 2002), págs. 20 ss.; GALOPPINI. La responsabilità per fatto dei dipendenti: formazione ed evoluzione della fattispecie, en "Scintillae Iuris". Studi in memoria di G. Gorla, 3, Milano 1994, págs. 2.147 ss.; CARDILLI. Il ruolo della dottrina nella elaborazione del sistema: l'esempio della responsabilità contrattuale, en Roma e America. Diritto romano comune. Rivista di diritto dell'integrazione e unificazione del diritto in Europa e in America Latina 1 (1996), págs. 106 ss.; MICELI. Sulla struttura formulare delle "actiones adiecticiae qualitatis", cit., págs. 192 ss.; FERCIA, Criteri di responsabilità dell" exercitor. Modelli culturali dell'atribuzione di rischio e regime della nossalità nelle azioni penali "in factum contra nautas, caupones et stabularios", Torino 2002, págs. 10 ss.; PETRUCCI. Profili giuridici delle attività e dell'organizzazione delle banche romane, Torino 2002, págs. 161 s.; Neque enim decipi debent contrahentes'. Appunti sulla tutela dei contraenti con un'impresa nel diritto romano tardo reppublicano e del principato, en Il ruolo della buona fede oggetiva nell'esperienza giuridica storica e contemporanea, en Studi in onore di A. Burdese 3, Padova 2003, cit., pág. 94; Ulteriori osservazioni sulla protezione dei contraenti con gli institores ed $i$ magistri navis nel diritto romano dell'età commerciale, en IURA 53 (2002) pág. 28.

${ }^{51}$ Responsabilidad que se entiende limitada al peculio o al beneficio que obtenga el empresario (in rem verso), en ausencia o al margen de la praepositio. Vid. D. 15,1,47 pr. (Paul. 4 Plaut.); D. 14,3,17,1 y 4 (Paul. 30 ad. ed.)

${ }^{52}$ Cfr., PETRUCCI. Profili giuridici, cit., pág. 161; Orígenes romanísticos de la buena fe objetiva en la contratación mercantil, en Anuario Mexicano de Historia del Derecho 15 (2003) pág. 606. En la actualidad ha suscitado gran interés la STS de 9 de mayo de 2013 sobre las «cláusulas suelo» en las hipotecas. El Tribunal Supremo ha declarado nulas dichas cláusulas en aquellos supuestos en que se apreciara falta de transparencia en contratos de préstamo hipotecario a interés variable que se hubieran celebrado entre profesionales y consumidores. "Véase asimismo, en torno a esta misma problemática, el artículo «Una modesta proposición a favor de la transparencia», en El Notario del siglo XXI. Revista del Colegio Notarial de Madrid 49 (mayo-junio 2013) págs. 19 ss.

(C) UNED. Revista de Derecho UNED, núm. 17, 2015 
na fe que debe presidir las relaciones contractuales entre los miembros de una societas argentariorum y los terceros que entablan relaciones contractuales con aquéllos, en definitiva, con su clientela.

Sobre estas premisas resulta incuestionable la importancia que asumieron en la práctica bancaria romana las rationes o anotaciones que el banquero transcribía en su libro contable (liber o codex rationum) ${ }^{53}$ documentando, de este modo, todas las transacciones realizadas con sus clientes ${ }^{54}$. La panoplia de operaciones comprendi-

${ }^{53}$ Este libro contable recogería todas los negocios entre el banquero y sus clientes y su situación patrimonial, anotándose sucesivamente y mezcladas las entradas y salidas de patrimonio, las obligaciones derivadas de los negocios jurídicos o los bienes existentes, ya que las anotaciones contables por partida doble no se conocieron hasta la Edad Media. Del análisis de los textos relativos al edicto de ratinonibus edendis no se desprende que se utilizaran unos libros especiales para la actividad bancaria. El específico liber rationum del que habla Gayo (D. 2,13,10,2 (Gai. 1 ed. prov.)) sólo aparece mencionado una vez. Así, no podemos desdeñar otros libros utilizados comúnmente en el registro de la contabilidad en general, como: el tradicional Codex accepti et expensi, libro contable que recogía la situación patrimonial de cualquier paterfamilias; el Kalendarium, agenda que servía para anotar los pagos y, particularmente, los préstamos realizados, o los adversaria, notas o borradores provisionales de duración mensual que luego se transcribían en el libro contable. Vid., entre otros, LÉCRIVAIN. Trapezitai, en DS 5 (1877-1919), págs. 408 ss.; MITTEIS. Trapezitika, cit., págs. 259 ss.; JOUANIQUE. Le codex accepti et expensi chez Cicéron, en Revue historique de Droit francais et étranger 46 (1968) págs. 5 ss.; BARLOW. Bankers, moneylenders and interes rates in the Roman Republic, 1984, págs. 264 ss.; SACCONI. Ricerche sulla delegazione in diritto romano, Milano 1971, págs. 144 s.; THILO. Der "Codex accepti et expensi' im romischen Recht: ein Beitrag zur Lehre von der Litteralobligation, Göttingen 1980, págs. 109 ss.; BOVE. Tabellae Eupliae. Testationes ex codice accepti et expensi, en Sodalitas. Studi in onore di Antonio Guarino, vol. 4, Napoli 1984, págs. 1.861 ss.; VELASCO GARCÍA. Algunas observaciones sobre la societas argentaria, en Historia. Instituciones. Documentos 12 (1985) pág. 135; MASELLI. "Argentaria". Banche e banchieri nella Roma repubblicana. Organizzazione, prosopografia, terminologia, Bari 1986, págs. 105 ss.; CREMADES. El contrato literal, en Derecho romano de obligaciones: Homenaje al Prof. J. L. Murga, Madrid 1994, págs. 519 ss.; PETRUCCI. Mensam exercere Studi sull'impresa finanziaria romana (II sec. a. C.- metà III sec. d. C.), Napoli 1991, págs. 168 ss.; ANDREAU. Pouvoirs publics et archives des banquiers professionnels, en La mémoire perdue. A la recherche des archives oubliées, publiques et privées de la Rome Antique, Paris 1994, págs. 1 ss.; GARCÍA GARRIDO. El comercio, los negocios y las finanzas en el Mundo Romano, Madrid 2001, págs. 109-110; RODRÍGUEZ GONZÁLEZ. El receptum argentarii, Madrid 2004, págs. 138; 152-155.

${ }^{54}$ Sobre el contenido de la ratio o cuenta bancaria véase la definición de Labeón, referida por Ulpiano, en D. 2,13,6,3 (Ulp. 4 ed.): Rationem autem esse Labeo ait ultro citro dandi accipiendi, credendi, obligandi solvendi sui causa negotiationem: nec ullam rationem nuda dumtaxat solutione debiti incipere. nec si pignus acceperit aut mandatum, compellendum edere: hoc enim extra rationem esse. sed et quod solvi ‘constituit', argentarius edere debet: nam et hoc ex argentaria venit. En torno al texto vid. FERNÁNDEZ BARREIRO. La previa información del adversario en el proceso privado romano, Pamplona 1969, págs. 155 ss.; ALBANESE. Agere, gerere e contrahere in D. 50,16,19, en SDHI 38 (1972) págs. 189 ss.; SANTORO. Il contratto nel pensiero di Labeone, en AUPA 37 (1983) págs. 160 ss.; PETRUCCI. Prime riflessioni su banca ed interessi 
das dentro de la gestión de las sociedades argentariorum testimoniadas por las fuentes resulta de gran variedad: algunas de ellas (depósito, crédito en subastas, receptum, la relativa a la liquidación de bienes hereditarios y no hereditarios ${ }^{55}$ ) son consideradas típicas ${ }^{56}$; mientras que otras, como los nomina transcriptia, o los mutuos garantizados con la entrega de una prenda, son comunes del resto de agentes financieros ${ }^{57}$.

De todo ello dan cuenta las fuentes, y es precisamente a partir de la conjugación de sus datos que pueden deducirse la existencia de algunas hipótesis de desarrollo de actividades societarias bancarias, aun cuando no siempre se disponga de testimonio directo de las mismas.

El Digesto incluye un pasaje de Labeón, citado por Ulpiano, respecto de las operaciones comprendidas en una cuenta bancaria-verdadero espejo de las relaciones obligatorias externas de la societas argentariorum con los terceros clientes-, todas ellas recíprocas entre el banquero y el cliente, y consistentes en dar y recibir, cargar y abonar, y, finalmente, obligarse y pagar, además de que en opinión de Ulpiano $^{58}$, también la promesa de asumir una deuda del cliente (salvo buen fin) es propia de la actividad argentaria, por lo que se incluye en la cuenta, resultando que todos los asientos contables deben ser exhibidos por los distintos socii argentariorum, de acuerdo con la disposición edictal (edictum de argentariis rationibus edendis): Rationem autem esse Labeo ait ultro citro dandi accipiendi, credendi «debendi», obligandi solvendi sui causa negotiationem: nec ullam rationem nuda dumtaxat solutione debiti incipere. Nec si pignus acceperit aut mandatum "susceperit», compellendum edere: hoc enim extra rationem esse. Sed et quod solvi constituit, argentarius edere debet: nam et hoc ex argentaria venit. (Más dice Labeón que la cuenta es un negocio recíproco de dar y recibir, de tener a crédito y deber, de obligarse y pagar: y que ninguna cuenta tiene inicio en la nuda paga de

nell'esperienza romana, en Atti del Convegno "L'usura ieri ed oggi», a cura di S. Tafaro, Bari 1997, págs. 80 ss.; Profili giuridici, cit., págs. 23 ss.; CERAMI- PETRUCCI. Diritto commerciale romano. Profilo storico, 3. a ed., Torino 2010, págs. 116 ss.

${ }^{55}$ Véase ANDREAU, Les affaires de Monsieur Jucundus, Roma 1974, págs. 73 y ss.

${ }^{56}$ Polibio cuenta cómo Escipión Emiliano [185-129 a. C.] ordena a un trapecita, que puede traducirse -se dice- por argentario, pagar a las hermanas de su padre adoptivo la suma que les debía por su dote. Trapecita, como ilustran los diccionarios, viene del griego «trapézion», diminutivo de «trápeza», equivalente a «mesa».

${ }^{57}$ Los argentarii concentraban originariamente el conjunto de dichas operaciones, pero desde comienzos del siglo II d. JC., son desarrollas también por los coactores argentarii y por los nummularii, sin olvidar que la intermediación en las subastas, era ajena a éstos últimos.

${ }^{58}$ D. 2, 13, 6, 3 (Ulp. 4 ed.) 
lo debido. Y que tampoco si ha recibido una prenda o ha asumido un mandato, debe ser compelido a exhibir: en efecto, ello está fuera de la cuenta. Pero el banquero debe también exhibir lo que ha prometido que será pagado, porque también esto corresponde a la «empresa» bancaria).

Por tanto, la cuenta argentarii cobra entidad propia, lo cual opera como presupuesto para deducir cuáles son las operaciones típicas de los socios argentarii, y cuáles deben ser excluidas ${ }^{59}$, pero a pesar de que todas ellas corresponden a una y otra parte (ultro citro negotiatio), no cabe calificarla como contrato a pesar Del intercambio de voluntades que se manifiesta de modo evidente y de manera continua$\mathrm{da}$, fruto de una reciprocidad consolidada ${ }^{60}$, se la tendencia de convertirse la cuenta argentarii, al menos, en soporte o armazón de las diferentes relaciones jurídicas que agrupa ${ }^{61}$ causa societati, que se abstrae y cobra autonomía respecto de ellas durante toda su existencia, de forma que, en cualquier caso, su cancelación no entraña per se la extinción de las obligaciones nacidas de los negocios incluidos en ella, como se pone de manifiesto en un texto de Escévola ${ }^{62}$, que se refiere al cierre de una cuenta ante una mensa nummularia:

Lucius Titius Gaium Seium mensularium, cum quo rationem implicitam habebat propter acepta et data, debitorem sibi constituit et ab eo epistulam accepit in haec verba: «ex ratione mensae, quam mecum habuisti, in hunc diem ex contractibus plurimis remanserunt apud me ad mensam meam trecenta octaginta sex et usurae quae competierint; summam aureorum quam apud me tacitam habes, refundam tibi. Si quod instrumentum a te emissum a te emissum, id est scriptum, cuiscumque summae ex quacumque causa apud me remansit, vanum et pro cancellatur habebitur». Quaesitum est, cum Lucius Titius ante hoc chirographum Seio numulario mandaverat, uti patrono eius trecenta redderet, an proper illa verba epistulae, quibus omnes cautiones ex quocumque contractu vanae et pro cancellato ut haberentur cautum est, neque ipse neque filii eius eo nomine conveniri possunt. Respondi, si tantum ratio accepti atque expensi esset computata, ceteras obligationes manere in sua causa.

${ }^{59}$ La conceptualidad de la cuenta aporta una conexión orgánica a las operaciones bancarias: en esto se basa la exclusión de dar una prenda, o la asunción de un mandato, operaciones éstas que resultan de lo más excepcional dentro de las relaciones externas de la societas argentariorum con clientes terceros. $C f r$., PETRUCCI-CERAMI, Lezioni di Diritto commerciale romano, Turín 2002, págs. 80-82.

${ }^{60}$ No queda abierta por el simple pago, al margen de la voluntad de los banquero de constituirla como tal.

${ }^{61}$ Se podría incluir en ella, v.gr., un depósito irregular según expresa Ulpiano en D. 16, 3, 7, 2 (Ulp. 30 ed.), o una gestión realizada en cumplimiento de un encargo o espontánea-D.2, 13, 6, 5 (Ulp. 4 ed.)-.

${ }^{62}$ D. 2, 14, 47, 1 (Scaev. 1 dig.) 
(Lucio Ticio constituyó deudor suyo al banquero Gayo Seyo, con quien tenía una compleja cuenta a causa de lo recibido y dado, y recibió una carta ${ }^{63}$ en estos términos: «De la cuenta bancaria que has llevado conmigo, por razón de muchos contratos, hasta el día presente quedaron en mi poder, en mi banco, trescientos ochenta y seis más los intereses que te corresponden; te reembolsará la suma no registrada de monedas de oro que tienes conmigo. Si cualquier documento por ti emitido -es decir, escrito- por cualquier causa y cualquier suma ha quedado en mi poder, será vano y cancelado». Se preguntó si a causa de las palabras de la carta, con las que se estableció que todas las promesas basadas en cualquier contrato fueran consideradas vanas y como canceladas, habiendo encargado Lucio Ticio al banquero Seyo, antes de este quirógrafo, restituir trescientos a su patrono, él mismo o sus descendientes pueden ser demandados. Respondí que, si sólo se ha computado la cuenta de lo dado y recibido, las otras obligaciones subsisten.)

A la luz de la definición descriptiva de la cuenta o ratio en el pasaje de Labeón citado por Ulpiano antes expuesto ${ }^{64}$ y el contenido de este último texto de Escévola, podemos cuestionarnos si la cuenta ${ }^{65}$, como entidad abstracta de las operaciones que alberga, constituye per se una fuentes de responsabilidades pecuniarias independientes de las derivadas de los actos y contratos integrados en dicha cuenta. Y si ello es así, ¿cómo se articularía en la praxis tal responsabilidad? Aproximándonos a la mecánica concreta de dichas cuentas, la responsabilidad que de las mismas pudiera generarse residiría en la producción de intereses, contra los socii argentarii o contra los clientes, con independencia de los negocios que dieron origen a las mismas.

Pues bien, de la lectura del texto expuesto de Escevola, se desprende que el argentarius, a la vista de la cancelación de la cuenta referida y de los varios contratos en ella referidos, reconoce al cliente un remanente de capital e intereses, fruto de la efectividad de una respon-

${ }^{63}$ Cfr., DE SARLO. Il documento oggetto di rapporti giudirici, Padua 1936, págs. 315 y ss.

${ }^{64}$ D. 2, 13, 6, 3 (Ulp. 4 ed.)

${ }^{65}$ Velasco García entiende que "Los nomina transcripticia (libros de cuentas corrientes) eran en sí mismos generadores de obligación a través de un efecto novatorio, ya fuese por cambio de la causa ( $a$ re in personam) como cuando el banquero anota como deuda a un vendedor lo que se le debe como precio, o bien con cambio de persona (a persona in personam), como siempre que actúa como intermediario de un cliente». Vid., VELASCO GARCÍA, Algunas observaciones sobre la societas argentaria, cit.

Véase, asimismo, ARNO. Il contrato de società, Torino 1938, p.100; Valiño, Instituciones de Derecho Privado Romano, Valencia 1976, págs. 514-515. 
sabilidad pecuniaria generada en favor del mismo. De la literalidad del mencionado texto puede colegirse que el devengo de intereses, debidos al cliente al momento de la cancelación, tiene su causa desdoblada, manifestándose de forma combinada, tanto en la cuenta (ex ratione mensae), como en los contratos en cuestión (ex contractibus plurimus). Esto quiere decir, que la inscripción o toma de razón en una cuenta bancaria, como negocio novatorio (a re in personam), era capaz de producir consecuencias simétricas, en la medida en que se comunicaría la causa obligationis del negocio original productor de intereses a la cuenta o ratio en sí misma considerado.

Asimismo, como la cuenta se apoya en un principio de bilateralidad, tales intereses también podrían generarse a favor de los argentarii, fruto de operaciones activas o de sobregiro, lo cual encuentra su apoyo en los testimonios aportados por las fuentes ${ }^{66}$. Ahora bien, ¿qué acciones específicas podían esgrimirse para exigir el pago de los intereses devengados ex ratione?

Hay que distinguir: primero si se trata de intereses contra los miembros de una societas argentarii, podría ejercitarse la actio de pecunia constituta, siempre y cuando hubiera mediado una promesa de pagar una deuda propia (constitutum debiti propii), al cabo de transcurrido un determinado plazo de tiempo desde la cancelación de la cuenta. En contraste, si los intereses han de ser reclamados al cliente, no se excluiría la típica acción de repetición, la condictio. De todas formas, hay que tener en cuenta que a partir del Emperador Adriano, merced a la competencia concurrente del praefectus urbi en las causas pecuniarias en las que intervenga un argentarium, podía accionarse por vía extraordinaria.

La fluidez en el funcionamiento y desarrollo de las actividades financieras exigían inexorablemente su publicidad manifestada a través de la comunicación al cliente con cierta regularidad de los extractos sobre las operaciones bancarias realizadas, la obligación de tener las cuentas al día operando compensaciones a favor de los diversos clientes, así como la exhibición del libro contable con indicación de las entradas y salidas constituirían obligaciones inherentes al oficio propio de los socii argentarii ${ }^{67}$. Una vez más, la corrección y transparen-

${ }^{66}$ PLAUTO. Aulularia 529-530; Trinummus 425.

${ }^{67}$ Vid. D. 2,13,6,6 (Ulp. 4 ed.); D. 2,13,10,2 (Gai. 1 ed. prov.); D. 2,14,47,1 (Scaev. 1 dig.); D. 50,16,56 pr. (Ulp. 62 ed.); CICERÓN, Pro Rosc. II,7. En este sentido, HUMBERT. Argentarii, en C. Daremberg and E. Saglio, Dictionnaire des Antiquité Grecques et Romaines, Graz 1969, pág. 408; TOZZI. Economistas griegos y romanos, Mexico 1974, págs. 397 y ss.; PENALVER. La banca en Roma, Madrid 1980, págs. 52 ss.; PETRUCCI. Profili giuridici, cit., pág. 163. 
cia que ha de existir en la contabilidad del banquero se fundamenta en la fides (D. 2,13,9,2) e interés público del servicio que presta. Según Gayo en D. 2,13,10,1 (Gai. 1 ed. prov.), a los argentarii se les impone el deber de confeccionar diligentemente las cuentas de sus negocios y publicarlas, y ello "quia officium eorum atque ministerium publicam habet causam» ${ }^{68}$.

Esta obligación se inserta, como podemos observar, en el Título 13 del libro II del Digesto, en el que se contienen los comentarios jurisprudenciales al edictum de argentariis rationibus edendis ${ }^{69}$ (cuyo origen podemos situar en el curso del siglo II a. C. $)^{70}$, sobre la obligación del argentarius de mostrar en juicio el contenido de los libros contables cuando cualquier cliente los necesite alegar en un litigio ${ }^{71}$. Su texto ha sido transmitido por Ulpiano (4 ad ed), compilado en dos pasajes $^{72}$, uno de los cuales recuerda estas palabras: Praetor ait: «Argentariae mensae exercitores rationem, quae ad se pertinet, edant adiecto die et consule». (Dice el Pretor: «Que los titulares de un banco exhiban la cuenta que les corresponde, con indicación del día y del año del cónsul»). La otra cita del jurista de Tiro se centra en la prescripción del edicto que ordena la exhibición previa autorización del magistrado, en el caso que se solicite por segunda vez o que el banquero sea el solicitante: Praetor ait: "Argentario eive, qui iterum edi postulabit, causa cognita edi iubebo». ( Dice el Pretor: "previa cognición de la causa, ordenaré que se exhiba al banquero o a quien pida la exhibición por segunda vez».

Efectivamente, el edicto impone a los banqueros edere rationes, es decir, presentar en juicio, o en los trámites previos al mismo, su libro de cuentas en la parte referente a las partidas de sus clientes que lo hubieran solicitado, con indicación del día y el año, teniendo pleno

${ }^{68}$ Ideo autem argentarios tantum neque alios ullos absimiles eis edere rationes cogit, quia officium eorum atque ministerium publicam habet causam et haec principalis eorum opera est, ut actus sui rationes diligenter conficiant.

${ }^{69} \mathrm{El}$ Título «De edendo» recoge, en realidad, comentarios a dos edictos: uno, referente a la obligación preprocesal de todo demandante de indicar la fórmula y los medios de prueba que va hacer valer en el proceso y el otro, de argentarii rationibus edendis. Cfr., RODRÍGUEZ GONZÁLEZ. El receptum argentarii, cit., págs. 135 ss.

${ }^{70}$ En una época en la que la actividad bancaria habría tenido ya un importante papel en la economía romana, vid. PETRUCCI. Mensam exercere. Studi sull'impresa finanziaria romana ( II sec. a. C.- metà III sec. d. C.), Napoli 1991, págs. 141 ss.; Profili giuridici, cit., pág. 104.

${ }^{71}$ Además del cliente, estaban legitimados para solicitar la editio, el procurator, el heredero (Ulp. 4 ad ed. D. 2,13,13) y el adquirente del negocio bancario. FERNÁNDEZ BARREIRO. La previa información del adversario en el proceso privado romano, Pamplona 1969, pág. 188.

${ }_{72}$ D.2.13.4, pr. (Ulp. 4 ed.) y D. 2.13.6.8 (Ulp. 4 ed.) 
valor de prueba escrita y sin que ello suponga la cancelación de la cuenta -D. 2,13,4 pr. (Ulp. 4 ed.): Praetor ait: "Argentariae mensae exercitores rationem, quae ad se pertinet, edant adiecto die et consule ${ }^{73}$. La ratio del edicto descansa, como indica Ulpiano (D. $2,13,4,1)$, en la aequitas, concretada en la necesidad de exhibir con fines probatorios los apuntes contables que han sido redactados en interés y por causa del propio cliente, y que se consideran en cierta manera de su propiedad ${ }^{74}$ :

Huius edicti ratio aequissima est: nam cum singulorum rationes argentarii conficiant, aequum fuit id quod mei causa confecit meum quodammodo instrumentum mihi edi.

En este contexto de tutela de la confianza de quien contrata con un argentarius, las prescripciones del edicto que, en principio, se referirían a los argentarii [D. 2,13,4 pr. (Ulp. 4 ed.)] se amplían por parte de la jurisprudencia, a los nummularii ${ }^{75}$, porque -a juicio de Pomponio, tal y como nos refiere Paulo [D. 2,13,9,2 (Paul. 3 ed.)]- no es injusto que también los cambistas estén obligados a comunicar sus cuentas, porque también ellos las confeccionan y, en parte, reciben dinero y, en parte, lo entregan; y, porque muy a menudo se recurre a la fe de los mismos:

Nummularios quoque non esse inquum cogi rationes edere Pomponius scribit: quia et hi nummularii sicut argentarii rationes conficiunt, quia et accipiunt pecuniam et erogant per partes, quarum probatio scriptura codicibusque eorum maxime continetur: et frequentissime ad fidem eorum decurritur.

Los testimonios interpretados por la jurisprudencia permiten al intérprete poder integrar algunos de los elementos estructurales de esta fuente del ius honorarium; y de este modo permitirían esclarecer los extremos siguientes: quiénes estaban obligados por el edicto; el

${ }^{73}$ El tenor original del edicto, según la reconstrucción de Lenel (EP, Leipzig 1927, págs. 61 ss.), comúnmente aceptada por la doctrina, sería el siguiente: Argentariae mensae exercitores ei qui iuraverit non calumniae causa postulare se edi sibi rationem quae ad se pertinet, edant adiecto die et consule. Vid. FERNÁNDEZ BARREIRO. Ibidem., para la reconstrucción de la fórmula de la acción correspondiente.

${ }^{74}$ Cfr., ANDREAU. Banque et affaires dans le monde romain, 2001, pág. 93.

${ }^{75}$ Petronio narra, como García Garrido nos recuerda en op. cit., que cuando se le preguntó a Trimalcón, liberto acaudalado, que qué oficio, además del de literato, consideraba más difícil, este contestó que el de médico y el del nummulario, el de nummulario porque los cambistas, dijo, ven el cobre [que hay dentro de la moneda, se entiende] a través de la plata [que es lo que en la superficie visible de la moneda aparece, debe entenderse]. Cfr., GARCÍA GARRIDO. El comercio, los negocios y las finanzas, cit.

Nummus, como nos dicen los diccionarios, significa moneda; y algunos de ellos nos traducen nummullarius por «banquero, cambista». 
objeto y lugar de la editio ${ }^{76}$, y, como corolario de los anteriores elementos, la forma que revestía la orden del pretor.

Tal obligación de exhibir puede recaer en el filius familias y en el servus, en los términos que se recogen en el texto de Ulpiano ${ }^{77}$ : «Sed filius familias continetur his verbis, utvel ipse cogatur Eder: an et pater, quaeritur. Labeo scribit patrem non cogendum, nisi sciente eo argentaria exercetur: sed recte Sabinus respondit tunc id admittendum, cum patri quaestum referte. Sed si servus argentariam faciat (potest enim), si quidem voluntate domini fecerit, compellendum dominum edere ac perinde in eum dandum ese iudicum, ac si ipse fecisset. Sed si inscio domino fecit, satis ese dominum iurare eas se rationes non habere. Si servus peculiarem faciat argentariam, dominus de peculio vel de in rem verso tenetur: sed si fominus habet rationes nec edit, in solidum tenetur». (Pero también está comprendido el hijo de familia en estas palabras, de suerte que él mismo sea obligado a exhibir; pero se pregunta si acaso también el padre. Labeón escribe que no debe obligarse al padre, salvo si sabiéndolo él se ejerciera la actividad bancaria; Sabino respondió acertadamente, que esto se ha de admitir cuando al padre corresponde la ganancia. Pero si un esclavo hiciere de banquero, (como es posible) si lo fuera con el consentimiento de su dueño, éste ha de ser compelido a la exhibición y contra él se ha de dar la acción, exactamente como si él mismo hubiese sido banquero. Pero si lo fue ignorándolo su dueño, es bastante que el señor jure que no lleva aquellas cuentas. Si el esclavo ejerciera como banquero con su peculio, o de lo que se convirtió en su provecho; pero si el señor tiene las cuentas y no las presenta, queda obligado solidariamente.

Asimismo, esta obligación también puede pesar sobre los herederos del socio argentarii ${ }^{78}$ : Cogentur et successores argentarii edere rationes. Quod si plures sont heredes et unus habeat, solus ad editionem compelletur: sed si omnes habeant et unus ediderit, omnes ad editionem compellendi sunt. Quid enim si humilis et deploratus unus edidit, ut dubitare quis merito de fide editionis possit? Ut igitur comparari

${ }^{76}$ El lugar de presentación de los libros y cuentas se determina en D. 2, 13, 4,5 (Ulp. 4 ed.) y D. 2, 13, 6 pr. (Ulp. 4 ed.) El primer texto reza así: Sed ibi quis compellitur edere, ubi argentariam exercuit, et hoc est constitutum. quod si instrumentum argentariae in alia provincia habeat, in alia administraverit, ibi puto cogendum edere, ubi argentariam exercuit: hoc enim primum deliquit, quod alio instrumentum transtulit. quod si in alio loco argentariam exercet, alibi autem ad editionem compelletur, minime hoc facere cogitur: nisi descriptum velis ubi de ea re agitur eum tibi dare, tuis videlicet sumptibus: El segundo: Si quis ex argentariis, ut plerique eorum, in villa habeat instrumentum vel in horreo: aut ad locum te perducet aut descriptas rationes dabit.

${ }_{77}^{7}$ D. 2, 13, 4, 2-3 (Ulp. 4 ed.)

${ }^{78}$ D. $2,14,25$, pr. (Paul. 3 ed.) 
rationes possint, etiam ceteri edere debent aut certe unius editioni subscribere. Hoc idem erit et si plures fuerint argentarii, a quibus editio desi deratur; nam et si plures tutores tutelam administraverunt simul, aut omnes edere debent aut unius editioni subscriber. (También los sucesores del banquero estarán obligados a exhibir las cuentas. Mas si son varios los herederos, y uno las tuviera, él sólo será compelido a la exhibición; pero si las tuvieran todos, y uno las hubiere presentado, todos han de ser compelidos a la exhibición. Mas ¿qué se dirá si las exhibió uno tan humilde e infeliz, que con razón pueda alguien dudar de la fe de la exhibición? En este caso, para que puedan compararse las cuentas, deben exhibirlas también los demás, o ciertamente suscribir la exhibición de aquél. Lo mismo se observará si hubieran sido muchos los banqueros de quienes se desea la exhibición; porque también cuando muchos tutores administraron juntamente la tutela, o todos deben exhibir; o suscribir la exhibición de uno solo).

Desde este punto de vista, resulta comprensible que la solicitud de exhibición no entrañe la cancelación de la cuenta, de acuerdo con un pasaje de Pomponio (6 ad Sab.): "Inter "edere" et "reddi rationes" multum intereset: nec is, qui edere iussus sit, reliquum reddere debet: nam et argentarius edere rationem videtur, etiamsi quod reliquum sit apud eum, non solvat. (Entre "exhibir" y "rendir cuentas" hay mucha diferencia y aquél a quien se le ordena que las exhiba no debe mostrar el saldo: porque también se considera que el banquero exhibe la cuenta, aunque no pague el saldo que queda en su poder».

Respecto a las societas argentariorum, exigen textos que atestiguan que el lugar donde se desempeña la actividad, es diferente de aquél en el que se llega la contabilidad o editio ${ }^{79}, 80$.

Por lo que respecta a las formas y solemnidades de llevarla a cabo, la orden de exhibición revestía la forma de decretum del pretor y representaba el momento a partir del cual el juez debía referir el id quod interest del cliente, en caso de incumplimiento de la misma ${ }^{81}$, a tenor de lo dispuesto en D. 2,13,8,1 (Ulp. 4 ed.): Is autem, qui in hoc edictum incidit, id praestat, quod interfuit mea rationes edi, cum decerneretur a praetore, non quod hodie interest: et ideo licet interesse desiit

${ }^{79}$ Ver, además de los textos de Ulpiano expuestos en la nota inmediatamente anterior, téngase en consideración D. 5, 1, 45, pr. (Pap. 3 resp.)

${ }^{80}$ De la lectura de los textos expuestos en las dos notas anteriores, puede deducirse que los mismos socii argentariorum pudieran desarrollar su actividad en varios lugares, incluso distintos entre sí.

${ }^{81}$ Cfr., BÜRGE. Zum Edikt De edendo. Ein Beitrag zur Struktur des römischen Zivilprozesses, en ZSS 112 (1995) págs. 37 s. 
vel minoris vel pluris interesse coepit, locum actio non habebit neque augmentum neque deminutionem.

Este mismo razonamiento sostenido por Ulpiano en D. 2,13,8,1 (Ulp. 4 ed.), más arriba expuesto, se repite en la primera parte de D. 2,13,10,3 (Gai. 1 ed. prov.): Cum autem in id actio competit, quanti agentis intersit editas sibi rationes esse: eveniet, ut, sive quis condemnatus sit, sive quod petierit non optinuerit eo, quod non habuerit rationes ex quibus causam suam tueri possit, id ipsum, quo dita perdiderit, hac actione consequatur...

Gayo pone de manifiesto que la acción que deriva del edicto compete por el importe del interés que el actor tuviera en el momento de la editio rationum, de modo que si alguno ha perdido el litigio y resulta condenado, o no ha obtenido lo que pedía por no tener las cuentas en las cuales haber podido fundar su demanda, podrá reclamar por medio de la acción adversus argentarios el equivalente a lo perdido a causa de la falta de editio ${ }^{82}$. Así pues, como podemos deducir del texto en cuestión, el cliente no quedaba desprotegido jurídicamente, sino que para que pudiera obtener tal resarcimiento de los daños por parte del banquero le era concedida una actio personal ${ }^{83}$ in factum, basada sobre la omisión de la editio rationum ${ }^{84}$; es decir, basada en un hecho (y no en un oportere como las fórmulas in ius conceptae), mediante la cual es magistrado sanciona tal conducta como inconveniente (y generalmente dolosa), aunque no esté reprimida por el ius civile. Tal

${ }^{82}$ También concede el jurista, al final del texto, la condictio ex causa furtiva y la actio damni iniuriae, en caso de hurto o falsificación (o deterioro) de los documentos contables, si se hubiera perdido el proceso en el que era necesario presentar estos documentos robados o corrompidos y en cuanto fuera posible demostrar el propio derecho: sic enim et de cautione subrepta aut corrupta competit condictio et damni iniuriae actio: quia quod ante non potuimus intercepta cautione probare et ob id amisimus, hoc nunc aliis instrumentis aut testibus, quibus tum uti non potuimus, probare possumus.

${ }^{83}$ Nunca in rem; vid. D’ORS, en Iura 1969, pág. 52; contra Kaser III, pág. 238, n. 44.

${ }^{84}$ Que fuera una acción in factum se desprende de un fragmento de PAULO (D. 2,13,9 pr. (Paul. $3 \mathrm{ed}$.)), donde se excluye su aplicación a otras categorías de sujetos, asimismo obligados a exhibir sus cuentas, como consecuencia de un vínculo contractual o cuasi contractual, tales como el procurador, el socio o el tutor. Ciertamente, estas personas no están, según Paulo, obligadas a la exhibición por la acción in factum, sino por la actio mandati, la actio pro socio o la actio tutelae, respectivamente: Quaedam sunt personae, quas rationes nobis edere oportet nec tamen a praetore per hoc edictum compelluntur. veluti cum procurator res rationesve nostras administravit, non cogitur a praetore per metum in factum actionis rationes edere: scilicet quia id consequi possumus per manditi actionem. et cum dolo malo socius negotia gessit, praetor per hanc clausulam non intervenit: est enim pro socio actio. sed nec tutorem cogit praetor pupilo edere rationes: sed iudicio tutelae solet cogi edere. 
actio in factum, al no referirse a un derecho que pide el demandante, no tiene propiamente intentio, sino una indicación de la omisión editio rationum (que tampoco es propiamente una demonstratio), de cuya comprobación depende la condemnatio. Además, al carecer de intentio, dicha acción no era susceptible de ficción ni de transposición de personas, al no hacer referencia inmediatamente al ius.

En concreto, la acción se contempla contra aquél que no hubiera respetado la prescripción pretoria de exhibir las cuentas y, por tanto, esta omisión se sanciona como un ilícito pretorio. Por lo demás, la obligación de edere no sólo resulta si el banquero es parte procesal en el procedimiento o controversia, sino que también se requiere su contabilidad para ofrecerla como prueba en un juicio del cliente contra un tercero ${ }^{85}$, según atestigua Gayo en D. 2,13,10 pr. (Gai. 1 ed. prov.): Argentarius rationes edere iubetur: nec interest cum ipso argentario controversia sit an cum alio.

Así, la acción in factum surge no como violación de las obligaciones contractuales inherentes a la ratio, sino como un verdadero y propio ilícito penal privado, con la finalidad de resarcir el daño patrimonial causado por una conducta ilícita del banquero ${ }^{86}$. El Pretor

${ }^{85}$ Ello se explica, como pone de relieve, Rodríguez González «porque formaban parte de las rationes aquellas operaciones que el argentarius realizaba con terceros en interés de su cliente». Vid., RODRÍGUEZ GONZÁLEZ. El receptum argentarii, cit., pág. 137.

${ }^{86}$ Sobre la naturaleza de la actio in factum adversus argentarios, como acción penal o acción ad exhibendum se ha discutido mucho en la doctrina, ya que participa de los elementos propios de las acciones penales, por ejemplo en cuanto su anualidad e intransmisibilidad pasiva (D. 2,13,13: Haec actio neque post annum neque in heredem nisi ex suo facto dabitur), pero puede pensarse también en características propias de una actio ad exhibendum, como la necesidad de probar el interés positivo del actor para la concesión de la acción (legitimatio ad causam). Vid. éstos y otros argumentos a favor de la naturaleza ad exhibendum de la acción en GIOMARO. Actio in factum adversus argentarios, en Studi Urbinati, 45, (1976-77), págs. 96 s. Cfr., en cambio, la opinión de la doctrina mayoritaria sobre su naturaleza penal, BIONDI. Le actiones noxales nel diritto romano classico, en Annali del Seminario Giuridico dell'Università di Palermo 10 (1926), pág. 63; BERETTA. Le formule in id quod interest, en SDHI 3 (1937), pág. 421; BRASIELLO. Atto illecito, pena e risarcimento del danno. Corso di diritto romano, Milano 1957, pág. 53; ALBANESE. Studi sulla legge Aquilia, en Annali del Seminario Giuridico dell'Università di Palermo 21 (1950), págs. 93 ss.; Illecito (storia), ED 20, 1970, págs. 62 ss [= Scritti giuridici 1, Palermo, 1991, págs. 791 ss]; LIEBS. Die Klagenkonkurrenz im römischen Recht: zur Geschichte der Scheidung von Schadensersatz und Privatstrafe, Göttingen 1972, págs. 232 y 263; PETRUCCI. Mensam exercere, cit., págs. 158 ss.; Profili giuridici, cit., págs. 143 s.; GARCÍA GARRIDO. El comercio, los negocios y las finanzas, cit., pág. 110; BURILLO, Contribuciones al estudio de la actio ad exhibendum en derecho clásico, en SDHI 26 (1960) págs. 208 ss.; Recensión a Fernández Barreiro, en IVRA 21 (1970) págs. 282 ss. y FERNÁNDEZ BARREIRO,. La previa información del adversario, cit., págs. 127 ss., quienes sobre la base de una sustancial diferencia entre exhibere y 
podía improvisar la fórmula para cada caso (acción decretal) ${ }^{87}$. Ulpiano (D. 2,13,8 pr. (4 ed.)) expone, claramente, los criterios de responsabilidad bajo los cuales circunscribir esta conducta de quien no efectúa la editio:

Ubi exigitur argentarius rationes edere, tunc punitur, cum dolo malo non exhibet: sed culpam non praestabit nisi dolo proximam dolo malo autem non edidit et qui malitiose edidit et qui in totum non edidit.

El criterio de imputación de responsabilidad al banquero por omisión de la editio es, como se desprende del texto, el dolo ${ }^{88}$ y, probablemente, la alusión a la culpa lata fuera un añadido posterior al sentir clásico ${ }^{89}$. El jurista no ofrece un elenco exhaustivo de los casos de non edere dolo malo, sino que llama simplemente la atención sobre dos ejemplos en particular: la editio maliciosa y la editio parcial, cuando dice que se entiende que también dejó de comunicar las cuentas por dolo el que exhibió maliciosamente y el que no exhibió la totalidad de las mismas (dolo malo autem non edidit et qui malitiose edidit et qui in totum non edidit). En la primera hipótesis, se sanciona al banquero que cumple con la editio, pero lo hace con la intención de dañar a quien la solicita: por ejemplo falseando las cifras o haciendo resultar a su favor créditos que en realidad no existen y todo ello con la finalidad de causar un daño a la contraparte. En el segundo caso, en cambio, el argentarius no rehúsa a cumplir la editio, pero la cumple sólo

edere, vienen a mostrar la falta de coincidencia entre la finalidad de ambas acciones: ad exhibendum e in factum.

${ }^{87}$ Cfr. WESENER, en Studi Betti IV (1962) pág. 503. Para los bizantinos las acciones in factum son acciones improvisadas para supuestos no ordinarios, pero no parece haber sido éste el sentido clásico, según el cual la actio in factum es la que tiene una fórmula in factum concepta.

${ }^{88}$ Fernández de Buján entiende que «La conducta dolosa no impide la perpetuatio obligationis, lo que significa que el acreedor insatisfecho podrá interponer la correspondiente acción por la que reclamará la cosa debida o su equivalente económico». Vid., FERNÁNDEZ DE BUJÁN, F., Sistema Contractual Romano, Madrid, 3. ${ }^{\mathrm{a}}$ ed., pág. 128.

${ }^{89}$ La doctrina mayoritaria se muestra a favor de considerar fruto de interpolación las palabras "nisi dolo proximam". Cfr. DE MEDIO. Studi sulla culpa lata in diritto romano, en BIDR 17 (1905) págs. 5 ss. y BIDR 18 (1906), págs. 260 ss.; FERRINI. Manuale di Pandette, Milano 1908, pág. 578; BILDING. Culpa, culpa lata und culpa levis, en ZSS 39 (1918) pág. 24; ROTONDI. Scritti giuridici II, Milano, 1922, pág. 98; MAC CORMACK. Culpa, en SDHI 38 (1972) pág. 178, nt. 148; VOCI. Diligentia, custodia, culpa. I dati fondamentali, en SDHI 56 (1990) pág. 50. Quizá este criterio de responsabilidad se introdujera antes de Justiniano, hacia finales del siglo I d. C., época en que lo encontramos conceptualizado en algunos juristas. En este sentido PETRUCCI. Profili giuridici, cit., pág. 150, basándose en CANNATA. Sul problema della responsabilità nel diritto privato romano, Catania 1996, págs. 28 ss.; CARDILLI. L'obbligazione di "praestare" e la responsabilità contrattuale in diritto romano (II sec. a. C.- II sec. d. C.), Milano 1995, págs. 433 ss. 
parcialmente, ocultando datos. En ambos casos se presume el dolo y se considera que se incumple la obligación de edere rationes.

La limitación al dolo ${ }^{90}$ de la responsabilidad del banquero en el ámbito de este edicto -que ni siquiera los bizantinos ampliarían a la culpa, sino sólo a la culpa lata o grave- supone un contrapeso a la tutela de los intereses de los clientes y revela, de este modo, una propensión a salvaguardar también la actividad bancaria, por cuanto ella cumple un papel decisivo en la economía romana. De ahí, también, el requisito del iusiurandum non calumniae causa postulare edi sibi que vendría impuesto por el magistrado a quien demandara la editio, como se deduce de sendos comentarios de Ulpiano y Paulo:

D. 2,13,6,2 (Ulp. 4 ed.): Exigitur autem ab adversario argentarii iusiurandum non calumniae causa postulare edi sibi: ne forte vel supervacuas rationes vel quas habet edi sibi postulet vexandi argentarii causa.

D. 2,13,9,3 (Paul. 3 ed.): Ceterum omnibus postulantibus et iurantibus non calumniae causa petere rationes, quae ad se pertineant, edi iubet.

Se trata de un remedio dirigido a reprimir la calumnia ${ }^{91}$. Concretamente, la exhibición contable se subordina a un juramento por parte del cliente de no solicitarla por el mero interés de causar un perjuicio al banquero.

Así, Ulpiano pone el acento en la finalidad del juramento para el que pide la comunicación de las cuentas, que no va más allá de no vejar o perjudicar al banquero con una solicitud que, por ejemplo, implique una documentación inútil o de la que ya se esté en posesión. Paulo, por su parte, no añade más al respecto, sino que afirma el mismo requisito de iusiurandum non calumniae causa como principio general, sin proporcionar ejemplos específicos. Con todo, de ambos

${ }^{90} \mathrm{~F}$. Fernández de Buján entiende que «El deudor responde siempre por dolo, pues, no cabe exención de su responsabilidad. Así lo afirma un texto de Paulo, tomado de su libro III de comentarios al Edicto y recogido en el Título XIV del Libro II del Digesto que lleva por rubrica Sobre pactos». Vid., FERNÁNDEZ DE BUJÁN, F., Sistema contractual, cit., 129.

${ }^{91}$ El que hacen en juicio tanto el actor como el demandado al entablar la acción o al proponer la excepción para corroborar que no lo hacen por calumnia o vejar a su adversario sino porque creen que la justicia les asiste con cinco puntos particulares que los legisladores antiguos comprendieron en las siguientes frases latinas: Illud juretur, quod lis sibi justa videtur; Et si queretur, verum non inficietur; Nil promittetur; nec falsa probatio detur; Ut lis tardetur, dilatio nulla petetur.

Por otra parte, dice PAULO en D. 42, 2, de confesis, I: Ait praetor: "Eum, a quo iusiurandum petetur, solvere aut iurare cogam»; alterum itaque eligat est, qui quodammodo sua sententia damnatur» (Dice el Pretor: "Aquel a quien se pidiere juramento, le forzaré a pagar o a jurar». Elija, pues, el demandado lo uno o lo otro: o pague o jure; si no jura, será obligado por el pretor a pagar). 
textos se puede inferir que se trata de un juramento particular, a iniciativa del magistrado, quien obligaría a jurar al actor cuando le presentara la postulatio editionis, como presupuesto necesario a su intervención. Sobre la base de este juramento el pretor emitiría el decretum con el que impondría al banquero la presentación en juicio de las rationes pertinentes a la causa ${ }^{92}$.

Pero si la solicitud de exhibición debía cumplir tales precisiones, no es menos cierto que debía, asimismo, probarse una relación causal directa entre el incumplimiento del deber del banquero de edere rationes y la pérdida del litigio por parte del cliente. Así se expresa Gayo en diferentes partes de su discurso extraído de D. 2,13,10,3 (Gai. 1 ed. prov.):

...eveniet, ut, sive quis condemnatus sit sive quod petierit non optinuerit eo, quod non habuerit rationes ex quibus causam suam tueri possit, id ipsum, quod ita perdiderit, hac actione consequatur... si apud hunc iudicem, qui inter eum et argentarium iudicat, potest probare se illo iudicio, quo victus est, vincere potuisse...

En tales referencias textuales el jurista pone de manifiesto la necesidad de probar por parte del cliente este nexo causal entre la pérdida del litigio y el hecho de carecer de las cuentas solicitadas al banquero para defender su causa. Se trata, por tanto, de un ejemplo más de la exigencia de equilibrar los derechos de los clientes de una empresa bancaria con los intereses de ésta, a fin de evitar que la disciplina del edicto pudiera influirle negativamente.

En la misma línea, la exhibición de cuentas bancarias encuentra otro límite en lo determinado por Gayo en D. 2,13,10,2 (Gai.1 ed. prov.):

Edi autem ratio ita intellegitur, si a capite edatur, nam ratio nisi a capite inspiciatur, intellegi non potest: scilicet ut non totum cuique codicem rationum totasque membranas inspiciendi describendique potestas fiat, sed ut ea sola pars rationum, quae ad instruendum aliquem pertineat, inspiciatur et describatur.

El jurista entiende que se exhibe una cuenta si se hace desde el principio, pues en caso contrario no se podría entender ${ }^{93}$, pero limita la exhibición al hecho de que el cliente pueda examinar y copiar tan

92 Vid., GIOMARO. Actio in factum adversus argentarios, Milano 1977, págs. 68 ss.

${ }^{93}$ Cada página del Codex rationum comenzaba con la indicación de la fecha seguida del registro de la operación concreta, como se desprende de D. 2,13,6,6 (Ulp. 4 $e d$.). De ahí la necesidad del cliente de ver la documentación de su cuenta desde el inicio, para conocer las referencias cronológicas de las distintas operaciones contenidas en la misma. Vid., PETRUCCI. Mensam exercere, cit., págs. 168 ss. 
sólo aquella parte de las cuentas que le interesan a los fines probatorios para su controversia, no la integridad del libro contable o codex rationum. Se excluye, por consiguiente, de la publicidad todo aquello que no fuera relativo al litigio o controversia en curso $^{94}$.

Este testimonio gayano, concretamente, resulta de gran interés para la doctrina, porque en él se ha advertido el punto de partida histórico de la moderna disciplina del secreto bancario y, en general, de todas las garantías que han de observarse en las operaciones entre cliente y banca ${ }^{95}$.

Por último, dos textos del Digesto vinculados entre sí, correspondientes a los comentarios de Ulpiano ${ }^{96}$ y Paulo al edicto, ponen de manifiesto, nuevamente, el equilibrio entre las exigencias de la banca y la protección a los terceros que contratan con ella. En ambos textos se subordina tanto la solicitud de exhibición de cuentas por el mismo banquero, como la del cliente hecha por segunda vez, a una previa cognición de causa (causa cognita) y ponderación, por lo tanto, por parte del pretor de cada caso en concreto:

${ }^{94}$ Como expresa Andreau «Le banquier n'était tenu de produire (edere) que ce qui concernait le compte du client; ou bien il en fournissait une copie, ou bien il permettait la consultation de l'original, mais en se limitant aux écritures du compte du client -écritures considérées, d’une certain façon, comme étant la propriété du client. Cette production du registre ou d'une copie conforme n'impliquait ni que le compte fût clos, ni que le solde fût réglé par le client ou par le banquier». Vid., ANDREAU, Banque et affaires, cit., pág. 93.

${ }_{95}$ Cfr., GIOMARO. Actio in factum adversus argentarios, cit., págs. 99 ss.; PETRUCCI. Profili giuridici, cit., pág. 151; GARCÍA GARRIDO. El comercio, los negocios y las finanzas, cit., pág. 109. En relación al secreto bancario en nuestra doctrina mercantilista actual vid., a modo de ejemplo, EMBID IRUJO. Contrato bancario y cuenta corriente bancaria. Las prestaciones: el llamado "servicio de caja». El secreto bancario. El deber de información. La responsabilidad, en AA. VV., Contratos bancarios (coord. por R. Bonardell Lenzano; Dir. R. García Villaverde), Madrid 1992, págs. 91-114; GUILLÉN FERRE. El secreto bancario y sus límites legales (límites de derecho público), Valencia 1996; AZAUSTRE FERNÁNDEZ. El secreto bancario, Barcelona 2001; PEÑAS MOYANO. La supresión (parcial) del secreto bancario en el ámbito de la Unión Europea, en Revista de derecho bancario y bursátil, Año n. ${ }^{\circ} 23$, N. ${ }^{\circ} 93$ (2004) págs. 221-238; ADRIÁN ARNÁIZ. El alcance extraterritorial de las normas nacionales sobre el secreto bancario y la libre prestación de servicios en el marco de la Unión Europea, en Revista de derecho bancario y bursátil, Año n. ${ }^{\circ}$ 23, N. ${ }^{\circ}$ 95, (2004), págs. 157 184; MONROY ANTÓN,. La directiva 2003/48/CE, su ineficacia práctica y la posible vulneración del secreto bancario, en Revista de derecho bancario y bursátil, Año n. ${ }^{\circ} 25$, N. $^{\circ} 101$ (2006) págs. 233-239.

${ }^{96}$ Sobre la naturaleza penal (y no preparatoria) como las exhibitorias), no acaba de convencer el texto de Ulpiano (D.2.13.13 (Ulp. 4 ed.)), en el que afirma su intransmisibilidad pasiva y su anualidad), así como que se refiera a un interés positivo del cliente (en concepto de pena y no de indemnización). Tampoco podría aceptarse pacíficamente que el cliente sea propietario de la cuenta, de tal forma que su exhibición sea un medio preparatorio para reivindicar. 
D. 2,13,6,9-10 (Ulp. 4 ed.): Prohibet argentario edi illa ratione, quod etiam ipse instructus esse potest instrumento suae professionis: et absurdum est, cum ipse in ea sit causa, ut edere debeat, ipsum petere ut edatur ei... nam et ipsi argentario ex causa ratio edenda est: si naufragio vel ruina vel incendio vel alio simili casu rationes perdidisse probet aut in longinquo habere, veluti trans mare. 10. Nec iterum postulanti edi praetor iubet, nisi ex causa:

D. 2,13,7 pr. (Paul. 3 ed.): veluti si peregre habere quod primum editum est doceat: vel minus plene editum: vel eas rationes, quas casu maiore, non vero negligentia perdiderit. nam si eo casu amisit, cui ignosci debeat, ex integro edi iubebit.

En el primer texto, Ulpiano explica la motivación de fondo que existe para que se prohíba la comunicación de las cuentas a los propios miembros de la societas argentarii. La razón está en que éste ya se encuentra previamente informado, dado que el ejercicio de su profesión implica la tenencia de los documentos que solicita y sería un privilegio absurdo admitir su solicitud invirtiendo a su favor la carga de la prueba. Sólo se admitiría tal demanda en el caso de que el banquero pruebe haber perdido las cuentas en virtud de una justa causa, como la fuerza mayor (naufragio, derrumbamiento, incendio o suceso análogo) o que las tenga en un lugar lejano, como por ejemplo, en una provincia transmarina. Termina el testimonio ofrecido por Ulpiano, con la afirmación de que tampoco dispone el pretor que se haga la comunicación de cuentas a favor del cliente que lo reclama por segunda vez, a no ser que haya causa para ello. Dichas causas se encuentran en el sucesivo texto de Paulo ${ }^{97}$, tales como: que se pruebe que tiene lejos lo que se le exhibió por primera vez o que la exhibición anterior fuera incompleta, o bien que haya perdido las cuentas por fuerza mayor y no por negligencia. El razonamiento último está en que sólo si hay una causa justificada, el pretor procederá a la orden de editio: nam si eo casu amisit, cui ignosci debeat, ex integro edi iubebit.

En efecto, como se deduce de los textos aquí referidos, si es el banquero quien solicita la exhibición o el cliente por segunda vez, el pretor no decreta automáticamente la orden tras la solicitud, sino que toma conocimiento del asunto y la admite o deniega previa cognición de causa. De ahí la imposición de determinados límites para garantizar que la solicitud de editio fuera razonable.

En resumen, tras examinar este régimen pretorio sobre la contabilidad bancaria, magistralmente interpretada e integrada merced a

${ }^{97}$ D. 2, 13, 9, pr. (Paul. 3 ed.) 
la labor jurisprudencial, podemos considerar que el interés social por el desarrollo de la actividad bancaria exige, asimismo, que ésta sea adecuadamente disciplinada estableciendo un equilibrio entre la afirmación y consolidación de la banca con la tutela de los intereses de los terceros que se ponían en contacto con los miembros de las societates argentariorum. Efectivamente, en la jurisprudencia se percibe una clara preocupación por imponer a cargo de los socios al frente de una taberna argentaria ${ }^{98}$ el deber de informar ${ }^{99}$-con la debida publicidad- sobre su práctica y los términos de su actividad contractual, respondiendo ilimitadamente por su incumplimiento o su variación, en base al principio "neque enim decipi debent contrahentes» $\mathrm{y}$ al concepto de «riesgo generado en la actividad económica y comercial».

De la obligación de los argentarii de llevar al día la contabilidad de los clientes, se desprende la institución del agere cum compensatio$n e^{100}$, como forma de pago abreviado o técnica generalizada para la extinción de las obligaciones ${ }^{101}$. Esto explica que en el caso de demandar el socius argentarii a su cliente ${ }^{102}$, éste está obligado sólo a reclamar el crédito residual, previa compensación, lo cual obedece al propósito de favorecer siempre al cliente, incluso si el banquero no la

${ }^{98}$ Véase al respecto, Cambridge Ancient History, vol. IX The Last Age of the Roman Republic 146-43 B. C.; 2 . $^{\text {a }}$ ed. Editado por J. A. Crook, Andrew Linott y Elizabeth Rawson, 1994, págs. 656-688.

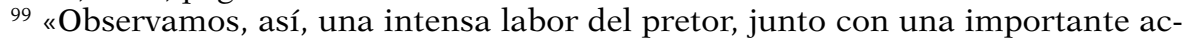
tividad interpretativa de la jurisprudencia, dirigidas a dotar al Derecho de una serie de previsiones relativas a la protección de la parte más débil de la relación contractual, tales como el deber de información de los productos bancarios con la correcta publicidad de la praepositio institoria, junto con el deber de corrección y transparencia de la contabilidad bancaria que impone el edicto de rationibus argentariis edendis. Además de la responsabilidad in solidum del banquero en caso de bancarrota o vulneración de los principios generales de la equidad y la buena fe. La ratio que descansa en toda esta disciplina está en el carácter de servicio público del argentariam facere». Vid., SALAZAR REVUELTA, El deber de información, transparencia y responsabilidad ante los depósitos de los clientes por parte de la banca: Precedentes romanos, en RIDR 2013.

${ }^{100}$ Se define por Modestino en D. 16, 2, 1 (Mod. 6 pandect.), diciendo: Compensatio est debiti et crediti inter se contributio. (La compensación es el balance de una deuda y de un crédito entre sí).

101 «En el derecho justinianeo, desaparecido ya el procedimiento formulario, la compensación se convierte en institución única y de valor general». Vid., IGLESIAS. Derecho Romano, Barcelona, pág. 489.

${ }^{102}$ Según Gayo $(4,67-68)$, es preciso que las deudas estén vencidas, e insiste en que la reclamación previa compensación no es facultativa para el argentarius, sino obligatoria, so pena de perder por pluris petitio, lo que explica que en virtud de que el objeto del litigio se encuentra determinado, y no sería posible que el juez condenara a otra cantidad más que en la expresada en la intentio de la fórmula. Vid. D'ORS. Derecho Privado Romano, cit., pág. 384. 
hubiera realizado, alegando que un cierto crédito no guarda relación con la cuenta: en tal caso, se concede una exceptio pensatae pecuniae para obligarle a ello ${ }^{103}$.

Asimismo, volvemos a insistir, antes de abordar el desarrollo de las relaciones de los socios argentarii erga omnes, por razón de la relación societaria constituida, en lo que ya expresamos en la pregunta anterior, respecto a la transmisión mortis causa de la obligación de llevanza y exhibición de cuentas bancarias, procediendo al análisis y comentario de un supuesto relativo al fideicomiso de un banquero gaditano, que expone Escévola ${ }^{104}$. Se trata de un caso en el que un testador había dejado un legado a dos hermanos Mevios en los siguientes términos: "Y todo lo que poseo en Cádiz, mi patria». Se preguntaba, entre otras cosas: En el caso de que dejara en la casa que tenía en Cádiz los documentos de crédito del registro de préstamos, que llevaba en su ciudad o en sus contornos, si también ese registro se debía entregar a los Mevios a causa del fideicomiso conforme a los términos del mismo. Asimismo se preguntaba si las cantidades que encontraran en la caja, en su casa de Cádiz, o las cobradas de diversos deudores y allí depositadas, se debían por el fideicomiso ${ }^{105}$.

Como justificación del sentido negativo de ambas cuestiones, podemos aducir: Por una parte, el causante, por su profesión de argentarius, tenía la obligación, como antes hemos expresado, de llevar un registro de cuentas e informar a los clientes de sus operaciones y saldos. Al responder los herederos de las deudas del banquero, debían conservar ellos los documentos y los registros que no debían entregar a los fideicomisarios. Por otra parte, las cantidades cobradas y depositadas debían servir para responder de las deudas del banquero y reembolsar los depósitos de los clientes. La continuación o liquidación de las operaciones de banca estaba a cargo de los herederos, y no entraban en el fideicomiso.

\section{RELACIONES FRENTE A TERCEROS REGIDAS POR EL PRINCIPIO DE SOLIDARIDAD}

Llegados a este punto, debemos cuestionarnos cuáles han sido los principios en virtud de los cuales se desenvuelve el comportamiento de los socios argentarii respecto de los terceros que se pongan en con-

${ }^{103}$ D. 22, 3, 19, 3 (Ulp. 7 disp).

${ }^{104}$ D. 32.41 .26 (Scaev. 22 dig.)

${ }^{105}$ Escévola responde en sentido negativo a ambas cuestiones. 
tacto con ellos. En las relaciones de los socii argentarii frente a terceros, regía el principio de la representación recíproca, traducido finalmente en la articulación de la responsabilidad societaria bajo el prisma de la solidaridad activa y pasiva de los mismos frente a terceros deudores o acreedores, según los casos. La existencia de la primera encuentra su fundamento en una fuente extra jurídica anónima ${ }^{106}$. En dicha Rhetorica se observa que puede demandarse también al socio del argentarius que haya efectuado el asiento contable. De esta manera, la doctrina constata que desde el siglo I a. JC., se había consolidado consuetudinariamente la solidaridad pasiva entre los socii argentarii y los terceros: "Consuetudine ius est id, quod sine lege aeque, ac si legitimum sit, usitatum est quod genus id quod argentario tuleris expensum, ab socio eius recte petere possis...» (... con base en la costumbre, el derecho es aquello que se usa sin que exista ley, como si fuera legítimo, y de este género es que cuanto hayas escrito y debe un argentario, justamente puedes pedirlo a su socio...».

El supuesto de hecho reflejado consiste en entregar una suma a un argentarius, de forma que asume la posición de deudor de su cliente. Por tanto, en la contabilidad bancaria queda asentado el crédito a través de una anotación llamada nomen transscriptium.

Lo mismo se refrenda en un pasaje de Paulo ${ }^{107}$.

Asimismo, Paulo nos viene a decir que siendo deudor un banquero socio, si pacta con su acreedor para que no se le exija la deuda (pactum de non petendo), ello aprovecha al socio, tal y como el pacto a favor de un deudor solidario por estipulación, puede oponerlo válidamente el otro, y lo mismo tendría lugar en la hipótesis en la que interviniera un fiador ${ }^{108}$.

En cuanto a la solidaridad activa, las fuentes testimonian que la gestión de uno de los banqueros -relacionada con el fin social-, justificaba la adquisición del crédito por parte de los socios, de modo que cada uno se encontraba facultado para exigirlo por entero, como se desprende del texto de Paulo ${ }^{109}$ : Si unus ex argentariis sociis cum debi-

${ }^{106}$ Rhetorica ad Herennium 2, 13, 19

107 D. 2, 14, 25, pr. (Paul. 3 ed.): Idem in duobus reis promittendi et duobus argentariis sociis. (Lo mismo vale para dos deudores por estipulación y para dos banqueros socios).

${ }^{108}$ Véase, D. 2, 14, 24 (Paul. 3 ad Plaut.): «Sed si fideussor in rem suam spopondit, hox casu fideiussor pro reo accipiendus est et pactum cum eo factum ese videtur».

${ }^{109}$ D. 2, 14, 27, pr. (Paul. 3 ed.) 
tore pactus sit, an etiam alteri noceat exceptio? Neratius, Atilicinus Proculus, nec si in rem pactus sit, alteri nocere: tantum enim constitutum, ut solidum alter petere possit. Idem Labeo... (Si uno de los socios banqueros hubiere pactado con el deudor "que no le reclamará», ¿perjudicará acaso también al otro la excepción? Neracio, Aticilino y Próculo dicen que no perjudica al otro pese a que el pacto sea sobre el objeto de la obligación: tan sólo se ha establecido que el otro sí que puede pedir el todo. Lo mismo opina Labeón...).

En consecuencia, en la societas argentarii primaba el pacto en virtud del cual, cada socio podía exigir solidariamente el cumplimiento de la obligación a sus clientes, aunque éstos hubieran celebrado el negocio con uno solo de ellos, y aun cuando uno de los banqueros hubiera pactado no exigir la satisfacción de la deuda (in rem), y no sólo no exigirla de manos de aquél con quien pactó (in personam $)^{110}$.

Asimismo, debemos recordar también que una de las características $^{111}$ del contrato de sociedad romano consiste en la falta de relevancia del vínculo social respecto a los terceros que hubiesen entrado en relaciones contractuales con socios singulares, salvo pacto expreso en contrario: Paulo D. 17, 2, 67 pr. (32 ed.): Si unus ex socii rem communem vendiderit consensu sociorum, pretium dividi debe ita, ut ei caveatur indemnem eum futurum, quod si iam damnum passus est, hoc ei praestabitur, sed si pretium communicatum sit sine cautione et aliquid praestiterit is qui vendidit, an, si non omnes socit solvendo sint, quod a quisbusdam servari non potest a ceteris debeat ferre? sed Proculus putat hoc ad ceterorum onus pertinere quod ab aliquibus servari non potest, rationeque defendi posse quoniam, societas cum contrahitur, tam lucri quam damni communio initur.

${ }^{110}$ El hecho de que la opinión de Labeón sea citada en este pasaje de Paulo, unido a la fecha de la Retórica, lleva a deducir que hacia finales de la República existía una simetría en el régimen de la solidaridad de la societas argentarii, dado que incluía tanto la activa como la pasiva. Asimétrica, en cambio, era la situación respecto de la conclusión de pactos de no exigir la deuda: en efecto, el argentarius deudor podía excepcionar oponiéndose de acuerdo con el pacto estipulado por su consocio, si bien el pacto celebrado por un socio acreedor no perjudicaba a los demás. Otros pasajes en los que existe pluralidad de socii argentarii, pero en los que la doctrina se debate entre la constatación o no de la solidaridad derivada de la sociedad entre ellos constituida, tanto activa como pasivamente, son también de PAULO, en D. 4, 8, 34, pr. (Paul. 13 ed.) y D.2, 14, 9, pr. (Paul. 62 ed.), respectivamente.

${ }^{111}$ Cfr., VELASCO GARCÍA. Algunas observaciones sobre la societas argentaria, cit., pág. 136. 
En definitiva, el régimen especial que se aplica a los socii argentarii concretado en la solidaridad activa y pasiva de los miembros de la mensa argentaria, así como la responsabilidad de los mismos con todo su patrimonio frente a los depósitos realizados en aquélla, ha sido calificado de ius singulare ${ }^{112}$.

${ }^{112}$ Cfr., Ibidem., pág. 139. Asimismo, véase CUYACIO. "At Semper excipio ab hac definitione argentarios socios, in quibus jus hoc ese consuetudine receptum Cornificis scribit secundo ad hernnium, ut quod, quis argentario expesnsum tulerit, id a socio argentarii in solidum repetere possit. Nec mirum, cum e diverso, quod quid argentario acceptum tulerit, id socius argentarii in solidum repetere possit, ut aperte dicitur jure singulari ese constitutum in. L. Si unus ex argent, in princ. sup.de pact. Hoc jure singulari in argentariis tantum sociis receptum est, non in caeteris sociis; falsum igitur, quod Cynus et Baldus generaliter statuunt, socium communi nomine mutuumin slidum accipientem, alterum socium obligare creditori in solidum conditioni creditae pecuniae, hoc est, creditorem, quod uni ex sociis expensum tulerit, id ab altero socio, cum quo non contraxit, in solidum repetere posse, quod receptum tantum est in argentariis sois propter necessarium usum argentariorum et mensae, propter utilitatem publicam, $l$. Quod prius. Depos. sicut et pleraque elia constat ese recepta singularia in argentariis ex Novel. 136». Vid., CUIACII., Opera Parisiensem Fabrotianam editionem, Tomo V, Prati 1861 c. 915 ad L. 82 pro Socio. 